\title{
The effect of redox conditions and bioirrigation on nitrogen isotope fractionation in marine sediments
}

J. Rooze ${ }^{\#}$ and C. Meile*

Department of Marine Sciences, The University of Georgia, Athens GA 30602, USA

\#jurjen@uga.edu

"cmeile@uga.edu

Submitted to Geochimica et Cosmochimica Acta 


\begin{abstract}
Nitrogen isotopic signatures of sources and sinks of fixed nitrogen $(\mathrm{N})$ can be used to constrain marine nitrogen budgets. However, the reported fractionation during benthic $\mathrm{N}_{2}$ production varies substantially. To assess the range and mechanisms responsible for such observations, we conducted a model study to evaluate the extent to which nitrification, denitrification, and anaerobic ammonium oxidation contribute to the isotopic composition of in situ $\mathrm{N}_{2}$ production. Different hydrodynamic regimes were taken into account, ranging from bioirrigation to diffusion-dominated transport. The benthic redox conditions were found to control the $\mathrm{N}$ isotope effect, which under reducing conditions is driven by fractionation during nitrification and anaerobic ammonium oxidation and under oxidizing conditions by fractionation during denitrification. Environmental parameters, such as the mineralization rate, the bioirrigation intensity, and chemical composition of the overlying water affect the benthic redox zonation and therefore also the benthic $\mathrm{N}$ isotope effect. The $\mathrm{N}$ isotope effect of benthic $\mathrm{N}_{2}$ production was computed for a wide range of bioirrigation intensities and mineralization rates, and found to be approximately $-3 \%$ for commonly encountered conditions. This value is similar to previous estimates of the global $\mathrm{N}$ isotope effect of benthic $\mathrm{N}_{2}$ production, and further constrains the relative importance of water column vs. benthic $\mathrm{N}_{2}$ production.
\end{abstract}

\title{
Introduction
}

The availability of nitrogen $(\mathrm{N})$ is considered one of the main controls of primary production in the ocean (Sarmiento and Gruber, 2006). Marine fixed N inventories are regulated mainly by microbial processes, which can induce $\mathrm{N}$ isotope effects by consuming or producing ${ }^{14} \mathrm{~N}$ and ${ }^{15} \mathrm{~N}$ species at slightly different rates. Therefore, the contributions from different sources and sinks to the bioavailable oceanic $\mathrm{N}$ pool can not only be determined from measured fluxes, but also constrained from their isotopic signatures (Montoya, 2008).

Globally, nitrogen fixation is the largest source and $\mathrm{N}_{2}$ production through denitrification (DNF) and anaerobic ammonium oxidation (anammox) represent the major sinks of 
bioavailable $\mathrm{N}$ in the ocean. $\mathrm{N}$ fixation introduces $\mathrm{N}$ with a $\delta^{15} \mathrm{~N}$ of $-1 \pm 1 \%\left(\delta^{15} \mathrm{~N}=\right.$ $\left\{\left[{ }^{15} \mathrm{~N} /{ }^{14} \mathrm{~N}\right] /\left[{ }^{15} \mathrm{~N} /{ }^{14} \mathrm{~N}\right]_{\text {standard }}-1\right\} * 1000 \%$; Minagawa and Wada, 1986; Carpenter et al., 1997). Anammox is carried out by chemolithoautotrophic bacteria that gain energy from the reaction of ammonium $\left(\mathrm{NH}_{4}{ }^{+}\right)$with $\mathrm{NO}_{2}{ }^{-}$to $\mathrm{N}_{2}$, with an $\mathrm{N}$ isotope effect of $-16 \%$ for $\mathrm{NO}_{2}{ }^{-}$reduction and approximately $-26 \%$ for $\mathrm{NH}_{4}{ }^{+}$oxidation (Brunner et al. 2013). During DNF, nitrate $\left(\mathrm{NO}_{3}{ }^{-}\right)$is reduced through several intermediates, including nitrite $\left(\mathrm{NO}_{2}{ }^{-}\right)$to dinitrogen gas $\left(\mathrm{N}_{2}\right)$. Although fractionation can occur during each step, the overall $\mathrm{N}$ isotope effect of the DNF pathway is affected most by the step in which a nitrogen-oxygen bond of a nitrate ion bound to nitrate reductase is cleaved (Shearer et al., 1991). In laboratory studies with marine denitrifying bacteria, fractionation by -5 to $-30 \%$ has been measured, depending on the specific denitrifier species and experimental conditions (Wellman et al., 1968; Granger et al., 2008; Kritee et al., 2012).

Strong $\mathrm{N}$ isotope fractionation of $-25 \pm 5 \%$ has been reported to occur during $\mathrm{N}_{2}$ production in oxygen minimum zones (Brandes et al., 1998; Altabet et al., 1999; Sigman et al., 2003). Due to this fractionation, $\mathrm{NO}_{\mathrm{x}}\left(\mathrm{NO}_{2}{ }^{-}+\mathrm{NO}_{3}{ }^{-}\right)$tends to become locally enriched in ${ }^{15} \mathrm{~N}$, which counters the discrimination against the preferential consumption of ${ }^{14} \mathrm{~N}$ and diminishes the effect on the bulk oceanic fixed $\delta^{15} \mathrm{~N}$ (Deutsch et al., 2004). Thus, the apparent enrichment factor of water-column $\mathrm{N}_{2}$ production is likely substantial, but less negative than the organism-level $\mathrm{N}$ isotope effect. In sediments the apparent $\mathrm{N}$ isotope effect was thought to be close to zero, since initial studies showed that the bottom water $\delta^{15} \mathrm{~N}^{-\mathrm{NO}_{\mathrm{x}}}$ did not change during incubation experiments (Brandes and Devol, 1997; Brandes and Devol, 2002; Lehmann et al., 2004). More recent studies have called the assumption of negligible $\mathrm{N}$ isotope fractionation into question. Firstly, fractionation during nitrification can produce light $\mathrm{NO}_{\mathrm{x}}$ substrate for $\mathrm{N}_{2}$ production and lead to exchange fluxes of heavy reduced $\mathrm{N}\left(\mathrm{NH}_{4}{ }^{+}+\right.$dissolved organic nitrogen [DON]) from the sediment to the overlying water, which then increases the ocean fixed $\delta^{15} \mathrm{~N}$ (Granger et al., 2011; Alkhatib et al., 2012). Secondly, $\mathrm{NO}_{\mathrm{x}}$ exchange fluxes have been found to directly communicate the benthic $\mathrm{N}$ isotope effect to the overlying water (e.g. Dale et al. 2014), which is consistent with observations in incubation experiment showing that $\mathrm{N}$ 
isotope fractionation during $\mathrm{DNF}$ led to heavier bottom water $\mathrm{NO}_{3}{ }^{-}$(Dähnke and Thamdrup, 2013).

In this study, we assess $\mathrm{N}$ isotope fractionation in sediments that are inhabited in bottom dwelling organisms. In particular near-shore environments are commonly inhabited by benthic infauna, which often are critical in shaping their habitat (Meysman et al., 2006a; Archer and Devol, 1992; Volkenborn et al., 2007). They enhance solute transport in sediments (Meile and Van Cappellen, 2003), increase benthic mineralization rates (Aller and Aller, 1998; Kristensen, 2001; D’Andrea and DeWitt, 2009), and promote higher coupled nitrification- $\mathrm{N}_{2}$ production rates (Grundmanis and Murray, 1977; $\mathrm{Na}$ et al., 2008). The study of sediment $\mathrm{N}$ cycling is particularly relevant on continental shelves, which host $50-65 \%$ of the global benthic $\mathrm{N}_{2}$ production (Middelburg et al., 1997; Bianchi et al., 2012; Bohlen et al., 2012). Approximately $70 \%$ of continental shelf sediments are permeable (Emery, 1968), so that advective transport typically dominates solute transport (Hüttel et al., 2003). Flow circulating through such sediment may introduce $\mathrm{NO}_{3}{ }^{-}$that is only partially consumed in situ, leaving the efflux enriched in heavy $\mathrm{N}$ to potentially communicate the $\mathrm{N}$ isotope effect of $\mathrm{N}_{2}$ production to the overlying water. Kessler et al. (2014) found that $\mathrm{N}_{2}$ production in a column experiment with current-induced flow led to an $\mathrm{N}$ isotope effect of approximately $-2.8 \%$. However, the effect of bioirrigation on benthic $\mathrm{N}$ isotope cycling has not yet been studied in detail. Here we present a mechanistic, early diagenetic process model to quantify the $\mathrm{N}$ isotope effect in sediment surrounding a burrow and identify the role of the redox conditions and advection induced by infauna in controlling the $\mathrm{N}$ isotope effect of benthic $\mathrm{N}_{2}$ production.

\section{Methods}

\section{Reaction transport model}

The mechanistic model simulated the effects of sediment early diagenesis in the presence of pumping infauna on the isotopic signature of benthic $\mathrm{N}$ fluxes. A 2D axisymmetric domain represented the physical 3D cylindrical environment surrounding a burrow, following the lugworm model of Meysman et al. (2006b). The domain radius was $10 \mathrm{~cm}$, 
which corresponds to a population density of $\sim 32$ individual organisms $\mathrm{m}^{-2}$. The uppermost $2 \mathrm{~cm}$ of the domain represented the bottom water, overlying $20 \mathrm{~cm}$ of sediment. A burrow feeding pocket was implemented as a fluid injection site of radius 2.5 $\mathrm{mm}$ located at $15 \mathrm{~cm}$ depth, with a feeding funnel above it that had a 10 times higher permeability than the rest of the sediment (Jones and Jago, 1993; Riisgård and Banta, 1998).

The method described in Dornhoffer et al. (2015) was used to simulate fluid flow. In short, flow velocities were calculated using the Navier-Stokes and Darcy-Brinkman equations (Le Bars and Worster, 2006), accounting for pressure forces and shear stress in the momentum balance. Fluid was injected into the sediment at a constant rate by imposing a normal velocity on the boundary of the feeding pocket. Symmetry conditions with zero normal flow were imposed at the outer cylinder boundaries. Zero normal flow was imposed at the bottom of the domain, while the top boundary allowed for fluid to escape.

The steady-state distribution of dissolved species was described by the following mass balance equation:

$$
0=\nabla \cdot\left(\phi D_{i} \nabla C_{i}-\phi v C_{i}\right)+R
$$

where $D_{i}$ is the diffusion coefficient, $C_{i}$ is the concentration, $\phi$ is the porosity (set to 1 in the overlying water), $v$ is the velocity vector, and $R$ is the net reaction rate. The molecular diffusion coefficients $D_{i}^{\text {mol }}$ were calculated following Boudreau (1997) at a temperature of $5^{\circ} \mathrm{C}$ and a salinity of 35 . In the bottom water the diffusion coefficient was the sum of $D_{i}^{m o l}$ and the eddy diffusion coefficient calculated with the Reichardt equation (Boudreau, 2001a):

$$
D_{i}=D_{i}^{m o l}+\kappa z u^{*}\left[1-\frac{11 v}{z u^{*}} \tanh \left(\frac{z u^{*}}{11 v}\right)\right]
$$

where $\kappa$ is the dimensionless von Karman constant $(0.4), z$ is the distance from the sediment-water interface, $u^{*}$ is the shear velocity (set to $10^{-3} \mathrm{~m} \mathrm{~s}^{-1}$ ), and $v$ is the kinematic viscosity $\left(10^{-6} \mathrm{~m}^{2} \mathrm{~s}^{-1}\right)$. The diffusion coefficient in the sediment was corrected for tortuosity in the porous medium following Boudreau (1996): 


$$
D_{i}=\frac{D_{i}^{\text {mol }}}{(1-2 \ln \phi)}
$$

The reaction network (Table 1) described mineralization of dissolved organic matter (DOM) in the sediment with aerobic respiration, DNF, and dissimilatory iron oxide $\left(\mathrm{Fe}(\mathrm{OH})_{3}\right)$ and sulfate $\left(\mathrm{SO}_{4}{ }^{2-}\right)$ reduction. The various mineralization reactions of labile DOM with different electron acceptors use a first-order rate law with respect to DOM concentration (Table 1). $\mathrm{NO}_{2}^{-}$was accounted for explicitly to implement anammox and to act as an intermediate in the DNF and nitrification reactions. Sulfide $\left(\mathrm{HS}^{-}\right.$) and dissolved iron $\left(\mathrm{Fe}^{2+}\right)$ can be reoxidized or form a FeS precipitate (Table 1). Reaction rates were set to zero in the overlying water, and processes such as dissimilatory nitrate reduction to ammonium, ammonium assimilation, or benthic primary production, which may become important in shallower waters, are not included. Strong mixing of the sediment by macrofauna was assumed to lead to a homogeneous distribution of solids in the sediment, and $\mathrm{POM}$ and $\mathrm{Fe}(\mathrm{OH})_{3}$ concentrations were held constant over the domain depth.

The parameterization of the baseline simulation was based on literature values, and within the reported ranges adapted to the setting of Brandes and Devol (1997). The measured benthic exchange fluxes of inorganic $\mathrm{N}$ and the $\mathrm{N}_{2}$ production rate were fitted by adjusting the benthic DOM production rate, the rate constants and half-saturation constants of nitrification, DNF, and anammox, and by adjusting the fractionation factors associated with $\mathrm{NH}_{4}{ }^{+}$consumption during anammox and nitrification (Table 2). At the top of the domain, known concentrations were imposed. For this, the bottom water concentrations of $\mathrm{O}_{2}$ and $\mathrm{NO}_{3}{ }^{-}$and the $\delta^{15} \mathrm{~N}$ of $\mathrm{NO}_{3}{ }^{-}$and organic matter reported by Brandes and Devol (1997) were used (Table 2). The concentrations in the oxygenated bottom water of reduced species $\mathrm{NO}_{2}{ }^{-}, \mathrm{NH}_{4}{ }^{+}, \mathrm{Fe}^{2+}$, and $\mathrm{HS}^{-}$were set to zero, and the DOM concentration was set to $50 \mu \mathrm{M}$ (Lønborg and Søndergaard, 2009). The same concentrations were also imposed at the feeding pocket, except that respiration by the macrofauna was assumed to produce $\mathrm{NH}_{4}{ }^{+}$and lead to a $60 \%$ oxygen drawdown in the fluid injected (Table 2). No flux conditions were imposed at the domain sides and bottom. 
The model was implemented in COMSOL4.4 using the "Free and Porous Media Flow" and "Solute Transport" application modes. The domain was discretized with approximately 23,000 triangular elements, with element sizes ranging from about $60 \mu \mathrm{m}$ to $1 \mathrm{~cm}$. The mesh was finest near the feeding funnel and sediment-water interface in order to resolve sharp concentration gradients accurately. All simulations were run dynamically to steady state.

\section{Nitrogen isotope fractionation}

For the dissolved $\mathrm{N}$ species separate state variables were included to account for ${ }^{14} \mathrm{~N}$ and ${ }^{15} \mathrm{~N}$. N isotope fractionation occurred through multiplying rate constants of the ${ }^{15} \mathrm{~N}$ species by fractionation factors, which are defined as $\alpha=\left(R^{\mathrm{h}} / R^{\mathrm{l}}\right) /\left({ }^{15} \mathrm{~N} /{ }^{14} \mathrm{~N}\right)_{\text {substrate }}$, where $R^{\mathrm{h}}$ and $R^{1}$ are the rates of reactions that consume ${ }^{15} \mathrm{~N}$ and ${ }^{14} \mathrm{~N}$ species, respectively (Table 1; Mariotti et al., 1981). The fractionation factors were generally less than 1, reflecting enzymatic discrimination against heavy $\mathrm{N}$ (Table 2). The only exception was $\mathrm{NO}_{2}{ }^{-}$ oxidation, which has an inverse $\mathrm{N}$ isotope effect (Casciotti, 2009).

The effect of the benthos on the isotopic composition of fixed $\mathrm{N}$ in the ocean is determined by the fluxes and isotopic composition of inorganic and organic $\mathrm{N}$ across the sediment-water interface. At steady-state the sum of these fluxes have to balance the magnitude and isotopic composition of the in situ $\mathrm{N}_{2}$ production, since DNF and anammox are the only sinks of $\mathrm{N}$ in the model. Therefore, the isotopic composition of the in situ produced gas can be used to quantify the $\mathrm{N}$ isotope effect $\left(\varepsilon_{s e d}\right)$ :

$$
\varepsilon_{\text {sed }}=\left[\frac{\left({ }^{15} \mathrm{~N} /{ }^{14} N\right)_{N_{2} \text { production }}}{\left({ }^{15} N /{ }^{14} N\right)_{\text {bottom water } N O_{3}}}-1\right] * 10^{3}
$$

where the $\mathrm{N}_{2}$ production rates are defined as:

$$
\frac{4}{3} R_{2}^{i}+R_{6}^{N O 2 i}+R_{6}^{N H 4 i}+2 R_{6}^{i i}
$$

with $i=\mathrm{h}$ for ${ }^{15} \mathrm{~N}$ and 1 for ${ }^{14} \mathrm{~N}$; $i i$ denotes anammox using nitrite and ammonium that are both heavy or light, respectively (Table 1). Burial of organic $\mathrm{N}$ is not taken into account, since the flux is small compared to the benthic and water-column $\mathrm{N}_{2}$ production rates (Brandes and Devol, 2002). 
The model can be used to quantify the contribution of individual processes to the isotopic composition of $\mathrm{N}_{2}$ produced in the sediment and hence the overall benthic $\mathrm{N}$ isotope effect,

$$
\varepsilon_{\text {sed }} \approx \delta^{15} \mathrm{~N}-\mathrm{N}_{2}-\delta^{15} \mathrm{~N}-\mathrm{NO}_{3, \mathrm{bw}}
$$

where $\delta^{15} \mathrm{~N}-\mathrm{N}_{2}$ and $\delta^{15} \mathrm{~N}-\mathrm{NO}_{3, \text { bw }}$ are the isotopic composition of the in situ produced $\mathrm{N}_{2}$ gas and $\mathrm{NO}_{3}{ }^{-}$in the overlying water, respectively. The isotopic composition of $\mathrm{N}_{2}$ produced from different sources in the absence of fractionation can be approximated by:

$$
\delta^{15} \mathrm{~N}-\mathrm{N}_{2}=f_{1} \delta_{1}+\cdots+f_{n} \delta_{n}
$$

where $f_{i}$ refers to the fraction of source $i$ (with a signature $\delta_{i}$ ). Fractionation in the conversion of substrate $s$ to product $p$ can be expressed as

$$
\delta p \approx \delta s+\varepsilon .
$$

Combining equations 7 and 8 yields:

$$
\delta_{N_{2}}=f_{1} \delta_{1}+f_{1} \varepsilon_{1}+\cdots+f_{n} \delta_{n}+f_{n} \varepsilon_{n}=A+\sum f_{i} \varepsilon_{i}
$$

Substitution into Eq. 6 shows that a simulation with all the fractionation factors ( $\alpha$, Table 2) set to 1 , which turns off fractionation in the model, yields an apparent $\mathrm{N}$ isotope effect $\left(\varepsilon_{\square}\right)$ that accounts for sources with a different $\mathrm{N}$ isotopic composition (organic $\mathrm{N}$ and bottom water $\mathrm{NO}_{3}{ }^{-}$) and is reflected in the parameter $A$ (Eq. 9)

$$
\varepsilon_{0} \approx A-\delta^{15} \mathrm{~N}-\mathrm{NO}_{3, \mathrm{bw}} \text {. }
$$

Next simulations were run with a single fractionation factor having its original value and all the others set to 1 , which yields an apparent $\mathrm{N}$ isotope effect $\left(\varepsilon_{j}\right)$. The apparent $\mathrm{N}$ isotope effect of individual processes $\left(\varepsilon_{k}=\varepsilon_{j}-\varepsilon_{0}\right)$ can then be combined to yield the overall benthic $\mathrm{N}$ isotope effect

$$
\varepsilon_{\text {sed }}=\varepsilon_{0}+\sum \varepsilon_{k}
$$

The effect of the areal bioirrigation intensity on benthic $\mathrm{N}$ isotope cycling was examined by changing the pumping rate $(Q$, Table 2$)$ and organism density, i.e. the domain radius. Simulations with a burrowing depth of $5 \mathrm{~cm}$ were performed to analyze the impact of shallow bioirrigation. The in situ DOM production rate $\left(F_{D O M}\right.$,prod, Table 2$)$, DOM reactivity $\left(k_{D O M}\right.$, Table 2$)$, and the composition of the overlying water $\left(\mathrm{O}_{2, \mathrm{bw}}\right.$ and $\mathrm{NO}_{3}{ }^{-}$,bw, 
Table 2) were varied to evaluate the benthic $\mathrm{N}$ isotope effect in different environmental settings.

Finally, sediment $\mathrm{N}$ fractionation was quantified for a wide range of mineralization rates and areal bioirrigation intensities. The latter is the pumping rate of an individual organism $\left(\mathrm{Q}\right.$, Table 2) divided by the domain surface area $\left(\mathrm{A}=\pi \mathrm{r}^{2}\right.$, Table 2$)$. In total 198 simulations were carried out in which the bioirrigation intensity and mineralization rates were varied from 4.6 to $91.7 \mathrm{~L} \mathrm{~m}^{-2} \mathrm{~d}^{-1}$ and 0.36 to $29.73 \mathrm{mmol} \mathrm{m}^{-2} \mathrm{~d}^{-1}$, respectively. Since burrowing macrofauna are dependent on the availability of POM as food source (Künitzer et al., 1992), sediment mineralization rates and bioirrigation intensities are often related. Two empirical relationships from literature were employed to provide a first order estimate of commonly encountered conditions, using the total sediment community oxygen consumption (SCOC) as a measure for the mineralization rate. The first relationship is based on an estimate of non-diffusive sediment $\mathrm{O}_{2}$ uptake (see Eq. 1 in Meile and Van Cappellen, 2003), which we tentatively assume to be due to bioirrigation. Recasting that equation and assuming a negligible amount of $\mathrm{O}_{2}$ in the sediment porewater yields:

$$
\frac{Q}{A}=\frac{S C O C}{O_{2, b w}}\left(1-\frac{1}{1.292+0.073 * S C O C}\right) * 1000
$$

where $\mathrm{Q} / \mathrm{A}$ is in $\mathrm{L} \mathrm{m}^{-2} \mathrm{~d}^{-1}$, SCOC corresponds to the mineralization rate in $\mathrm{mmol} \mathrm{C} \mathrm{m}{ }^{-2}$ $\mathrm{d}^{-1}$, and $\mathrm{O}_{2, \text { bw }}$ is the oxygen bottom water concentration in $\mu \mathrm{M}$ (Table 2).

The second method uses the equation derived by Fennel et al. (2009), which estimates the benthic $\mathrm{N}_{2}$ production rate $\left(F_{N 2}, \mathrm{mmol} \mathrm{N} \mathrm{m}^{-2} \mathrm{~d}^{-1}\right)$ as a function of SCOC:

$$
F_{N 2}=0.086111 * S C O C+0.17624
$$

Results for simulations with particulate-to-dissolved organic matter conversion ( $F_{D O M, p r o d}$, Table 2$)$ and pumping $(Q)$ rates, which match the relationship between SCOC and $\mathrm{F}_{\mathrm{N} 2}$ given in Eq. 13 were then identified. Since the sediment $\mathrm{N}_{2}$ production in the model is to a large extent dependent on the $\mathrm{NO}_{3}{ }^{-}$introduced through bioirrigation (see results), this allows identification of the corresponding bioirrigation intensity. 


\section{Results}

The distribution of solutes and reaction rates in the baseline simulation are shown in Fig. 1. $\mathrm{O}_{2}$ was restricted to a plume surrounding the feeding pocket (Fig. 1a), limiting the volume where aerobic remineralization and nitrification (Fig. 1d) can take place. The zone of $\mathrm{N}_{2}$ production through DNF and anammox (Fig. 1e), which are inhibited by $\mathrm{O}_{2}$ and limited by $\mathrm{NO}_{\mathrm{x}}$ availability (Fig. 1b), encapsulated this oxygenated zone. At a burrowing depth of $15 \mathrm{~cm}$ nearly all $\mathrm{NO}_{\mathrm{x}}$ produced in situ or pumped into the sediment was ultimately reduced to $\mathrm{N}_{2}$, while at a shallower burrowing depth of $5 \mathrm{~cm}$ the burrowassociated $\mathrm{NO}_{\mathrm{x}}$ plume extended across the sediment-water interface (see contour lines in Fig. 1b), enabling a significant fraction of the injected $\mathrm{NO}_{\mathrm{x}}$ to escape reduction to $\mathrm{N}_{2}$. Modeled $\mathrm{NH}_{4}{ }^{+}$concentrations were suppressed at the depth of the feeding pocket due to high consumption by nitrification and anammox (Figs. 1c and f). The $\mathrm{NO}_{3}{ }^{-}$profile peaked at the feeding pocket depth, while the $\mathrm{NO}_{2}{ }^{-}$concentrations remained below $4 \mu \mathrm{M}$ throughout the sediment domain. The lateral heterogeneity in the sediment allows the highest rates of aerobic and anaerobic processes to occur at the same depth (e.g. anammox and nitrite oxidation, Fig. 1f).

The benthic exchange fluxes measured by Brandes and Devol (1997) were reproduced in

the baseline simulation. The modeled benthic $\mathrm{O}_{2}$ uptake of $4.4 \mathrm{mmol} \mathrm{m} \mathrm{m}^{-1}$ and the magnitude and isotopic composition of the $\mathrm{NH}_{4}{ }^{+}$flux to the overlying water (Fig. 2a) matched their data. Bottom water $\mathrm{NO}_{3}{ }^{-}$with a measured $\delta^{15} \mathrm{~N}$ of $7.3 \%$ was pumped into the sediment and was reduced to $\mathrm{NO}_{2}{ }^{-}$. A small fraction of relatively light $\mathrm{NO}_{2}{ }^{-}$was able to escape further reduction and fluxed out to the overlying water (Fig. 2a). The resultant net $\mathrm{NO}_{\mathrm{x}}$ flux into the sediment of 7.5\%, combining an influx of bottom water nitrate of $7.3 \%$ with a nitrite efflux of $3.3 \%$, was slightly heavier than the bottom water $\mathrm{NO}_{3}{ }^{-}$and matched with the values reported in Brandes and Devol (1997). Denitrification of $\mathrm{NO}_{2}^{-}$ and anammox accounted for $63 \%$ and $37 \%$ of the benthic $\mathrm{N}_{2}$ production, respectively. The $\mathrm{N}_{2}$ production also matched that of Brandes and Devol (1997), but had a $\delta^{15} \mathrm{~N}$ of 5.2\% compared to the reported $1 \pm 4 \%$. Applying Eq. 4 the $\varepsilon_{\text {sed }}$ value was $-2.4 \%$. 
Sensitivity analyses were performed by changing the pumping rate (Fig. 3a), burrow density and burrow depth (Fig. 3b), the reactivity of DOM (Fig. 3c), the bottom water $\mathrm{O}_{2}$ and $\mathrm{NO}_{3}{ }^{-}$concentrations (Fig. $3 \mathrm{~d}$ and e), and the POM to DOM conversion rate (Fig. 3f). Each panel shows the $\mathrm{N}_{2}$ production rates (top) and the $\varepsilon_{\text {sed }}$ values (bottom), which together determine the effect of benthic $\mathrm{N}_{2}$ production on the isotopic composition of dissolved inorganic $\mathrm{N}$ in the overlying water. A lower pumping rate decreased the $\mathrm{N}_{2}$ production rate and led to a higher expression of the $\mathrm{N}$ isotope effect of anammox and nitrification (Fig. 3a). Conversely, higher pumping rates enhanced the $\mathrm{N}_{2}$ production and led to more fractionation due to DNF (Fig. 3a). Changing the domain radius, reflecting a different organism density, showed a similar pattern. Fractionation due to nitrification and anammox was more strongly expressed when the bioirrigation intensity was decreased (larger domain radius, Fig. 3b), while the fractionation induced by DNF was stronger when the bioirrigation intensity was increased (smaller domain radius). A shallower burrow depth of $5 \mathrm{~cm}$ reduced the $\mathrm{N}_{2}$ production rate and increased the $\mathrm{N}$ isotope fractionation of nitrification, anammox, and DNF (compare left and right group in Fig. 3b).

Lowering the reactivity of DOM by two orders of magnitude (to $k_{D O M}=2 * 10^{-7} \mathrm{~s}^{-1}$, Fig. $3 c$ ) led to a strong degree of $\mathrm{N}$ isotope fractionation. Fractionation during $\mathrm{NH}_{4}{ }^{+}$oxidation made $\varepsilon_{\text {sed }}$ less negative and thus had an apparent inverse $\mathrm{N}$ isotope effect. However, the effect on the isotopic composition of $\mathrm{NO}_{\mathrm{x}}$ in the overlying water was small (Fig. 2b), since the $\mathrm{N}_{2}$ production was very low (Fig. 3c, top panel). Lowering the reactivity of DOM by only one order of magnitude (to $k_{D O M}=2 * 10^{-6} \mathrm{~s}^{-1}$, Fig. $3 \mathrm{c}$ ), led to a slightly lower $\mathrm{N}_{2}$ production rate than in the baseline simulation. Fractionation during DNF had a large impact on $\varepsilon_{\text {sed }}$ and led to heavier $\mathrm{NO}_{\mathrm{x}}$ in the overlying water. A higher DOM reactivity $\left(k_{D O M}=2 * 10^{-5} \mathrm{~s}^{-1}\right.$ and $k_{D O M}=2 * 10^{-4} \mathrm{~s}^{-1}$, Fig. $3 \mathrm{c}$ ) had little effect on the $\mathrm{N}_{2}$ production rate, but led to less $\mathrm{N}$ isotope fractionation during DNF and slightly more fractionation during $\mathrm{NH}_{4}{ }^{+}$oxidation and anammox. The isotopic composition of the benthic $\mathrm{NO}_{\mathrm{x}}$ flux was similar to that of $\mathrm{NO}_{3}{ }^{-}$in the overlying water and had therefore a negligible effect on the $\delta^{15} \mathrm{~N}$ of $\mathrm{NO}_{\mathrm{x}}$ in the overlying water (Fig. 2b). Changing the rate of DOM to POM conversion had a moderate effect on the benthic $\mathrm{N}_{2}$ production rate 
(Fig. 3f) and the contribution of individual processes on $\varepsilon_{\text {sed }}$ values showed similar trends as changing the DOM reactivity.

The bottom water $\mathrm{O}_{2}$ concentration had a moderate effect on the $\mathrm{N}_{2}$ production rate, with maximum areal rates at $250 \mu \mathrm{M}$ (Fig. 3d). At higher $\mathrm{O}_{2}$ concentrations, fractionation during DNF led to substantially more negative $\varepsilon_{\text {sed }}$ values. The highest contribution of $\mathrm{NH}_{4}{ }^{+}$oxidation and anammox to the isotope effect of benthic $\mathrm{N}_{2}$ production was at relatively low $\mathrm{O}_{2}$ concentrations of $50-100 \mu \mathrm{M}$. The bottom water $\mathrm{NO}_{3}{ }^{-}$concentrations had a substantial effect on the benthic $\mathrm{N}_{2}$ production rates (Fig. 3e). The $\mathrm{N}$ isotope effect of $\mathrm{NH}_{4}{ }^{+}$oxidation and anammox was stronger at low $\mathrm{NO}_{3}{ }^{-}$concentrations, while fractionation during DNF was stronger at high $\mathrm{NO}_{3}{ }^{-}$concentrations.

Changing the mineralization rate and bioirrigation intensity simultaneously gives insight in the expression of the benthic $\mathrm{N}$ isotope effect in different environments. The $\varepsilon_{\text {sed }}$ values were most negative when either the irrigation intensity was high and the mineralization rate low or, conversely, the irrigation intensity low and the mineralization rate high (Fig. 4). Between these extremes, there was a relatively large region with $\varepsilon_{\text {sed }}$ values between -2.1 and $-4 \%$. The two lines in Fig. 4 that tentatively indicate which mineralization rates may be most typical for different bioirrigation intensities (see methods section) were similar for low bioirrigation intensities, but differed more substantially at higher values. Nonetheless, both $\varepsilon_{\text {sed }}$ values corresponding to these estimates of commonly encountered combinations of irrigation intensities and mineralization rates were generally less negative than $-3.5 \%$. A similar analysis conducted with a burrow depth of $5 \mathrm{~cm}$ (not shown) exhibited a similar pattern, but exhibited about 2-3\%o more negative $\varepsilon_{\text {sed }}$ values.

\section{Discussion}

\section{Benthic nitrogen processing and isotope fractionation}

Macrofauna can pump bottom water to depths in the sediment that without bioirrigation would be anoxic. The simulated redox zonation with an oxic plume surrounding the feeding pocket and anoxic conditions in the remainder of the sediment (Fig. 1a) are in 
line with studies on large burrowing macrofauna ( $\mathrm{Na}$ et al., 2008; Volkenborn et al., 2010). The modeled solute profiles showed pronounced accumulation of $\mathrm{NO}_{3}{ }^{-}$and depletion of $\mathrm{NH}_{4}{ }^{+}$at the feeding pocket depth (Fig. 1c), which is qualitatively consistent with profiles measured at sites with large burrowing macrofauna (Grundmanis and Murray, 1977; Hüttel, 1990; Volkenborn et al., 2007). At the Puget Sound site studied by Brandes and Devol $(1995,1997)$, measured $\mathrm{O}_{2}$ and $\mathrm{NO}_{3}{ }^{-}$concentrations approached zero in the uppermost centimeter of sediment, similar to the computed horizontally averaged concentration profiles (Fig. 1c), but no measurements were reported at greater depth in the sediment, where infauna present (Lie, 1968; Brandes and Devol, 1997; Nichols, 2003) may have affected $\mathrm{O}_{2}$ and $\mathrm{NO}_{3}{ }^{-}$concentrations. Sediment permeability and porosity constrains the environment in which bioirrigation can be a dominant transport process (Hüttel et al., 2003). However, since model simulations use an imposed pumping rate, the computed flow field is only impacted by spatial variations in permeability. The ten-fold higher permeability in the feeding funnel than in the bulk sediment leads to a slightly higher expulsion of porewater through this conduit. However, the overall effect on the benthic $\mathrm{N}$ exchange fluxes and expression of the $\mathrm{N}$ isotope effect was small $(\Delta \varepsilon=-0.1 \%)$. Similarly, variations in porosity have only a minor impact on fluxes and fractionation (not shown).

For a given organism density (reflected in the domain size), the pumping rate controlled the benthic exchange fluxes of $\mathrm{NO}_{\mathrm{x}}$ and $\mathrm{O}_{2}$, since the injected $\mathrm{NO}_{\mathrm{x}}$ and $\mathrm{O}_{2}$ were in most settings quantitatively consumed. For instance, in the baseline simulation all $\mathrm{O}_{2}$ and nearly all $\mathrm{NO}_{\mathrm{x}}$ from the plume were consumed before they could reach the sedimentwater interface (Fig. 1b). Areal pumping rates, which are a combination of the density of burrowing organisms and the individual pumping rates, were the same in the simulations with a domain radius $\mathrm{r}=10 \mathrm{~cm}$ and $\mathrm{Q}=0.16,0.62$, and $1.86 \mathrm{~mL} \mathrm{~min}^{-1}$ (Fig. 3a) and those with $\mathrm{Q}=0.62 \mathrm{~mL} \mathrm{~min}^{-1}$ and $\mathrm{r}=20,10$, and $5.8 \mathrm{~cm}$ (Fig. 3b, burrow depth $=15$ $\mathrm{cm})$, respectively. The corresponding bar plots are nearly identical. This indicates that the areal bioirrigation intensity controls the magnitude and isotopic composition of the $\mathrm{N}$ fluxes. 
The model simulations reproduced the benthic exchange fluxes reported by Brandes and Devol (1997) except that the isotopic composition of the in situ produced $\mathrm{N}_{2}$ gas differed by 4\% from the average measured value reported by Brandes and Devol (1997). Multiple factors could have played a role in causing this discrepancy. Firstly, determining $\mathrm{N}_{2}$ fluxes is challenging due to the high background concentrations of $\mathrm{N}_{2}$ in seawater (Hamersley and Howes, 2004), and uncertainties in isotopic signatures of fluxes can be substantial ( $\pm 4 \%$ in Brandes and Devol, 1997). Secondly, sediment $\mathrm{N}$ sources and sinks may be out of balance, while steady-state conditions were assumed in the model, which can lead to differences in modeled and observed benthic $\mathrm{N}$ fluxes and isotope effects. Finally, the model did not account for dissimilatory nitrate reduction to ammonium, connecting the oxidized and reduced dissolved inorganic $\mathrm{N}$ species, or for $\mathrm{NH}_{4}{ }^{+}$ assimilation, which could affect the isotopic composition of benthic DON exchange fluxes. Underestimating the efflux of heavy DON would result in an isotopically too heavy $\mathrm{N}_{2}$ efflux in the model. Alkhatib et al. (2012) have argued that DON fluxes can play an important role in communicating benthic $\mathrm{N}$ isotope effects to the overlying water. However, this contribution remains poorly constrained as neither Alkhatib et al. (2012) nor Brandes and Devol (1997) reported the $\delta^{15} \mathrm{~N}$ and flux of DON separately from $\mathrm{NH}_{4}{ }^{+}$.

In the sensitivity analysis the expression of the $\mathrm{N}$ isotope effect of individual processes ( $\varepsilon_{i}$, Fig. 3) is largely controlled by the benthic redox conditions. More oxidizing conditions correspond to higher injection rates of oxic bottom water into the sediment $(\mathrm{Q}$, Fig. 3a), higher organism densities (i.e. smaller domain radii, Fig. 3b), DOM with less reducing power (smaller $k_{D O M}$, Fig. 3c), more $\mathrm{O}_{2}$ and $\mathrm{NO}_{3}{ }^{-}$in the bottom water (Figs. 3d and e), the production of less reducing DOM (Fig. 3f), while the opposite trends correspond to more reducing conditions. Under oxidizing conditions discrimination against heavy $\mathrm{NO}_{3}{ }^{-}$during DNF is more strongly expressed, whereas under reducing conditions discrimination against heavy $\mathrm{NH}_{4}{ }^{+}$during $\mathrm{NH}_{4}{ }^{+}$oxidation and anammox is more pronounced. This reflects that the expression of $\mathrm{N}$ isotope fractionation at the cell level is dependent on the fraction of the benthic reactant pool that is being consumed (Mariotti et al., 1981; Lehmann et al., 2004). Under oxidizing conditions the sediment resembles a closed system for $\mathrm{NH}_{4}{ }^{+}$, consuming a larger fraction of the benthic $\mathrm{NH}_{4}{ }^{+}$ 
pool, and preventing the efflux of heavy $\mathrm{NH}_{4}{ }^{+}$caused by fractionation during $\mathrm{NH}_{4}{ }^{+}$ oxidation and anammox to the overlying water. Meanwhile, the sediment resembles a more open system towards $\mathrm{NO}_{3}{ }^{-}$and simulations that showed stronger expression of the fractionation during $\mathrm{NO}_{3}{ }^{-}$reduction $\left(\varepsilon_{\mathrm{NO}, \mathrm{DNF}}\right)$ had $\mathrm{NO}_{\mathrm{x}}$ plumes that extended from the feeding pocket to the sediment-water interface (e.g. Figs. 1b and 3b). The preferential consumption of light $\mathrm{NO}_{\mathrm{x}}$ in the sediment will then lead to a flux of $\mathrm{NO}_{\mathrm{x}}$ enriched in ${ }^{15} \mathrm{~N}$ to the overlying water. Conversely, under more reducing conditions, the system becomes more open towards $\mathrm{NH}_{4}{ }^{+}$as less $\mathrm{O}_{2}$ is available to oxidize it, while it becomes more closed towards $\mathrm{NO}_{3}{ }^{-}$, minimizing the expression of the $\mathrm{N}$ isotope effect of DNF.

The expression of a benthic $\mathrm{N}$ isotope effect depends on the fractionation occurring at the cell level, as well as the coupling between different reactions that compete for substrates. The latter can lead to an apparent inverse $\mathrm{N}$ isotope effect on the overall benthic $\mathrm{N}_{2}$ production, despite a fractionation factor $\alpha<1$, as seen for $\mathrm{NH}_{4}{ }^{+}$oxidation at low mineralization rates (Figs. $3 \mathrm{c}$ and $\mathrm{f}$ ). Since fractionation during this reaction leads to heavier $\mathrm{NH}_{4}{ }^{+}$and lighter $\mathrm{NO}_{2}{ }^{-}$, the inverse apparent $\mathrm{N}$ isotope effect (production of isotopically heavy $\mathrm{N}_{2}$ ) can only occur when a large amount of $\mathrm{NH}_{4}{ }^{+}$is converted to $\mathrm{N}_{2}$ and a part of the produced $\mathrm{NO}_{\mathrm{x}}$ escapes to the overlying water. This depends on the prevalent redox conditions, and requires anammox to be the dominant $\mathrm{N}_{2}$ production pathway, propagating the heavy residual $\mathrm{NH}_{4}{ }^{+}$signature into $\mathrm{N}_{2}$. When DNF dominates $\mathrm{N}_{2}$ production (as is the case at higher mineralization rates in Figs. $3 \mathrm{c}$ and $\mathrm{f}$ ), the $\delta_{\mathrm{N} 2}$ reflects largely the isotopic signature of the $\mathrm{NO}_{2}^{-}$and a "normal" negative apparent $\mathrm{N}$ isotope effect of $\mathrm{NH}_{4}{ }^{+}$oxidation is observed.

The impact of the benthic $\mathrm{N}$ isotope effect on the isotopic composition of fixed $\mathrm{N}$ in the overlying water is dependent on both $\varepsilon_{\text {sed }}$ and the $\mathrm{N}_{2}$ production rate. Thus, there is a stronger impact at high irrigation rates compared to conditions with low $Q$, as $\mathrm{N}_{2}$ production increases with the higher input of $\mathrm{NO}_{3}{ }^{-}$(Fig. 3a). Similarly, there is a very strong $\mathrm{N}$ isotope effect at the lowest DOM reactivity, but the impact on fixed $\mathrm{N}$ in the overlying water is negligible due to the extremely low $\mathrm{N}_{2}$ production rate (Fig. $3 \mathrm{c}$ ). In Fig. 3e the $\mathrm{N}$ isotope effect of $\mathrm{NH}_{4}{ }^{+}$oxidation and anammox is stronger at lower $\mathrm{NO}_{3}{ }^{-}$ 
bottom water concentrations. This is because at the same pumping rate less $\mathrm{NO}_{3}{ }^{-}$is injected, so that the $\mathrm{N}_{2}$ production and its isotopic signature are more dependent on fractionation during $\mathrm{NH}_{4}{ }^{+}$oxidation. At higher $\mathrm{NO}_{3}{ }^{-}$concentrations in the bottom water, the supply of $\mathrm{NO}_{3}{ }^{-}$to the sediment via bioirrigation increases. This stimulates $\mathrm{N}_{2}$ production and lowers the relative contribution of $\mathrm{NH}_{4}{ }^{+}$oxidation to the benthic nitrogen isotope effect (Fig. 3e).

\section{The effect of solute transport on benthic nitrogen isotope fractionation}

In bioirrigated sediment, $\mathrm{N}$ isotope cycling is dependent on the bioirrigation intensity and the burrowing depth (Figs. 3a and b). For shallow burrows, some of the injected $\mathrm{NO}_{\mathrm{x}}$ is flushed out the sediment before it can be reduced, which significantly enhances the expression of the $\mathrm{N}$ isotope effect of DNF. A shallow burrow depth also increases the expression of the $\mathrm{N}$ isotope effect of nitrification and anammox (Fig. 3b). Rates of these processes are highest within and around the oxic plume (Figs. 1d and e). When the plume extends across the sediment-water interface a larger fraction of $\mathrm{NH}_{4}{ }^{+}$produced in the sediment by organic matter mineralization escapes to the overlying water (Fig. 3b) and allows for expression of the $\mathrm{N}$ isotope effect of benthic $\mathrm{N}_{2}$ production. $\mathrm{NO}_{\mathrm{x}}$ injected at greater depth is less likely to escape to the overlying water, since the oxic plume surrounding the burrow and the sediment-water interface are than separated by a larger reducing zone, where DNF and anammox take place. When the injected $\mathrm{NO}_{\mathrm{x}}$ is quantitatively consumed DNF does not induce fractionation.

Our model results provide context for the interpretation of field observations. Lehmann et al. (2004) measured benthic $\mathrm{N}$ fluxes with incubation experiments in shelf sediments of the Santa Monica Bay, where bioirrigation plays an important role. They observed that the isotopic composition of $\mathrm{NO}_{3}{ }^{-}$did not change over time, which suggests that, similar to our baseline scenario, the $\mathrm{NO}_{3}{ }^{-}$was quantitatively consumed. In contrast, Dale $e t$ al. (2014) reported a strong benthic $\mathrm{N}$ isotope effect in hypoxic Mauritanian margin sediments. Their $\varepsilon_{\text {sed }}$ value was $-13 \%$ and appeared to be mostly communicated to the overlying water through $\mathrm{NO}_{\mathrm{x}}$ exchange fluxes. On photographs of the sediments burrow openings and other signs of macrofaunal activity were visible, consistent with substantial 
bioirrigation. Granger et al. (2011) estimated an $\varepsilon_{\text {sed }}$ value of -6 to $-8 \%$ based on measured light $\mathrm{NO}_{3}{ }^{-}$and heavy reduced $\mathrm{N}$ in bottom water of the Bering Sea shelf, and argued that partial nitrification of the benthic $\mathrm{NH}_{4}{ }^{+}$pool drove the $\mathrm{N}$ isotope effect of benthic $\mathrm{N}_{2}$ production. The benthic infauna was not identified in their study, but burrows are prevalent in Bering Sea shelf sediments (Davenport et al., 2012) exposed to large fluxes of POM (Baumann et al., 2013). Large $\mathrm{NH}_{4}{ }^{+}$effluxes are common in bioirrigated sediments (Na et al., 2008; Stief, 2013, Lehmann et al., 2004) due to enhanced mineralization rates (Aller and Aller, 1998; Kristensen, 2001) and the ejection of anoxic porewater (Volkenborn et al., 2010). Under these conditions, the $\mathrm{N}$ isotope effect of anammox and coupled nitrification- $\mathrm{N}_{2}$ production can be communicated to the overlying water through effluxes of isotopically heavy $\mathrm{NH}_{4}{ }^{+}$, which is consistent with our analysis (see for example the effect of higher mineralization rates in Figs. 3c and f).

The effect of bioirrigation can also be compared and contrasted with other transport regimes. Advective flow caused by pressure gradients, which may be the result of bottom currents over rippled sediment surfaces or the motion of waves, can lead to high $\mathrm{N}_{2}$ production in sediments (Boudreau et al., 2001b; Kessler et al., 2012). Based on combined water-column experiments and modeling Kessler et al. (2014) estimated that benthic $\mathrm{N}_{2}$ production in these sediments can lead to $\mathrm{NO}_{3}{ }^{-}$fluxing out of the sediment that is enriched by $3 \pm 1 \%$. Nitrification did not occur in their experiment, but their model indicated that including nitrification would have a small effect. DNF under advective flow regimes is mainly driven by $\mathrm{NO}_{3}{ }^{-}$from the overlying water, while coupling between nitrification and DNF is low (Kessler et al., 2012). This is in stark contrast to sediments with deeper bioirrigation, where the coupling between nitrification and $\mathrm{N}_{2}$ production is strong as all the $\mathrm{NO}_{\mathrm{x}}$ produced in the oxic plume surrounding the burrow is ultimately reduced to $\mathrm{N}_{2}$.

When the transport regime is dominated by diffusion, $\mathrm{NO}_{\mathrm{x}}$ fluxing into the sediment will be quantitatively consumed. In such a setting, a benthic $\mathrm{N}$ isotopic effect can still occur if the isotopic composition of the $\mathrm{NO}_{\mathrm{x}}$ fluxing into the sediment differs from that of bottom water $\mathrm{NO}_{\mathrm{x}}$. Models have indicated that the preferential consumption of light $\mathrm{NO}_{\mathrm{x}}$ in the 
sediment leads to a steeper gradient of ${ }^{14} \mathrm{NO}_{\mathrm{x}}$ than ${ }^{15} \mathrm{NO}_{\mathrm{x}}$, which then results into a net flux of light $\mathrm{NO}_{\mathrm{x}}$ into the sediment and consequently the in situ production of light $\mathrm{N}_{2}$ (Bender, 1990; Brandes and Devol, 1997). However, early studies showed that the isotopic composition of $\mathrm{NO}_{\mathrm{x}}$ in the overlying water did not change during incubation experiments, which could suggest that $\mathrm{N}$ isotope fractionation in the sediment was negligible (Brandes and Devol, 2002; Lehmann et al., 2007). It is also possible that the production of light $\mathrm{NO}_{\mathrm{x}}$ during nitrification can mask the preferential use of isotopically light $\mathrm{NO}_{\mathrm{x}}$ during DNF (Lehmann et al., 2007). This was observed in the simulation with bioirrigation turned off $\left(\mathrm{Q}=0\right.$, Fig. 3a) where $\varepsilon_{\text {sed }}$ was $-12.6 \%$, while the sediment $\mathrm{NO}_{\mathrm{x}}$ efflux was enriched by only $1.7 \%$. The $\mathrm{N}$ isotope effect is then communicated to the overlying water primarily through the efflux of heavy $\mathrm{NH}_{4}^{+}$. Qualitatively, this is in agreement with a benthic $\mathrm{N}$ isotope effect of up to $-7.2 \%$ modeled by Lehmann et al. (2007), who accounted for aerobic respiration, denitrification and nitrification only. It is also consistent with work by Dähnke and Thampdrup (2013), who showed experimentally that apparent $\mathrm{N}$ isotope fractionation during benthic DNF can occur in a setting where transport is dominated by diffusion. When diffusion is the only transport mechanism, a longer distance between the DNF zone and the sediment-water interface will decrease the benthic $\mathrm{N}$ isotope effect (Lehmann et al., 2007). Since this distance is dependent on the $\mathrm{O}_{2}$ penetration depth, higher bottom water $\mathrm{O}_{2}$ concentrations may cause less fractionation. However, higher $\mathrm{O}_{2}$ bottom water concentrations can also be associated with a smaller benthic $\mathrm{N}$ isotope effect in bioirrigated sediments (Fig. 3d). This illustrates that the impact of $\mathrm{O}_{2}$ on $\varepsilon_{\text {sed }}$ not only depends on other biogeochemical factors such as mineralization rates but also on the transport mechanisms.

\section{Benthic nitrogen isotope effects under commonly encountered environmental conditions}

Our simulations indicate that the $\mathrm{N}$ isotope effect will be strongest in surficial sediments that have either strongly reducing or oxidizing conditions (Figs. 3a and 4). Redox conditions strongly depend on the intensity of bioirrigation and the reaction rates consuming $\mathrm{O}_{2}$, reflected in mineralization rate. However, settings with high bioirrigation intensity and low mineralization rates or vice versa are relatively rare. These two competing factors commonly correlate, since OM rich settings with high rates of 
mineralization can support a large number of benthic infauna (Künitzer et al., 1992), which enhance the transport of oxidants into the sediment. Conversely, in areas where POM is scarce the bioirrigation intensity may be lower. By using the relationships between the bioirrigation intensity and benthic mineralization rates (see Eqns. 12 and 13) the model simulations predict that $\varepsilon_{\text {sed }}$ values in bioirrigated sediment are commonly close to $-3 \%$ (Fig. 4). However, there are a number of uncertainties associated with this estimate. Firstly, our simulations of shallower burrows indicate a larger benthic $\mathrm{N}$ isotope effect (Fig. 3b). However, smaller organisms are likely to pump less, and enhanced flow may also lead to conditions more comparable to the advective setting studied by Kessler et al. (2014). Secondly, N-cycling processes not considered in the model may also impact fractionation. Thirdly, comprehensive data sets on benthic $\mathrm{N}$ isotope cycling suitable for model parameterization are scarce, offering limited constraints on the model parameterization. For example, it is clear that fractionation factors in the field may differ from laboratory conditions, yet it is not well understood what causes the discrepancies between different studies (Kritee et al., 2012).

Bioirrigation is important in shallow marine environments where a significant part of the global $\mathrm{N}_{2}$ production takes places and therefore must have a large imprint on the global average $\mathrm{N}$ isotope effect of benthic $\mathrm{N}_{2}$ production $\left(\varepsilon_{g l o b}\right)$. Our estimate of $-3 \%$ being common for bioirrigated sediments is akin to previous estimates of $\varepsilon_{g l o b}$. Lehmann et al. (2007) estimated $-4 \%$, which is remarkably similar given the fact that they did not account for advective transport and considered a different set of early diagenetic reactions. Kessler et al. (2014) also found an $\mathrm{N}$ isotope effect of $\sim-3 \%$ for coastal sediment with transport dominated by wave-induced advection. Global circulation models coupled to $\mathrm{N}$ cycle models have tried to reproduce the measured $\mathrm{NO}_{3}{ }^{-}$ concentrations and isotopic composition in the ocean to spatially resolve pelagic and benthic $\mathrm{N}_{2}$ production rates. Using this approach, Somes et al. (2013) found best fits of the ocean fixed $\delta^{15} \mathrm{~N}$ with $\varepsilon_{g l o b}$ values between -2 and $-4 \%$. Such benthic fractionation has a significant impact on estimates of benthic vs. pelagic $\mathrm{N}_{2}$ production. Assuming steady-state and considering only nitrogen fixation as source and water-column and 
benthic $\mathrm{N}_{2}$ production as sinks, the fraction $f_{\text {benthic }}$ of benthic $\mathrm{N}_{2}$ production of the total $\mathrm{N}_{2}$ production can be estimated as

$$
f_{\text {benthic }} \approx \frac{\varepsilon_{f i x}-\delta^{15} \mathrm{~N}-\mathrm{N}_{\text {fix,avg }}-\varepsilon_{w c}}{\varepsilon_{g l o b}-\varepsilon_{w c}}
$$

where $\varepsilon_{f i x}$ is the $\mathrm{N}$ isotope effect of $\mathrm{N}$ fixation $(\sim-1 \%), \delta^{15} \mathrm{~N}-\mathrm{N}_{\text {fix,avg }}$ is the average isotopic composition of ocean fixed $\mathrm{N}(\sim 5 \%)$, and $\varepsilon_{w c}$ is the $\mathrm{N}$ isotope effect of watercolumn $\mathrm{N}_{2}$ production. Kritee et al. (2012), whose experiments indicated that turbulence and thermodynamically lower $\mathrm{N}$ isotope fractionation at the cell level, argued that $\varepsilon_{w c}$ might fall in the range of -10 to $-15 \%$, which is substantially different from earlier estimates such as the $-20 \%$ estimated by Brandes and Devol (2002). Furthermore, less apparent fractionation can be expected in oxygen minimum zones if $\mathrm{NO}_{3}{ }^{-}$becomes locally heavier than the average ocean $\delta_{\mathrm{NO} 3}$ (Deutsch et al., 2004). Using $\varepsilon_{w c}=-12.5 \%$ o and $\varepsilon_{g l o b}=-3 \%$, leads to $68 \%$ of total marine $\mathrm{N}_{2}$ production to taking place in the sediment. For water-column $\mathrm{N}_{2}$ production of $\sim 70 \mathrm{Tg} \mathrm{N} \mathrm{yr}^{-1}$ (Bianchi et al., 2012), the benthic $\mathrm{N}_{2}$ production rate would be $152 \mathrm{Tg} \mathrm{N} \mathrm{yr}^{-1}$. A $\pm 1 \%$ uncertainty in $\varepsilon_{g l o b}$ corresponds to global benthic $\mathrm{N}_{2}$ production rates between 114 and $228 \mathrm{Tg} \mathrm{N} \mathrm{yr}^{-1}$, which highlight the sensitivity of the ocean fixed $\delta^{15} \mathrm{~N}$ towards $\mathrm{N}$ isotope fractionation in sediments.

\section{Conclusion}

Redox conditions exert a major control on the $\mathrm{N}$ isotope effect of benthic $\mathrm{N}_{2}$ production, since they determine the extent to which different benthic $\mathrm{N}$ pools are consumed within the sediment. Fractionation against heavy $\mathrm{NH}_{4}{ }^{+}$during nitrification and anammox is enhanced under reducing conditions. Conversely, fractionation against heavy $\mathrm{NO}_{\mathrm{x}}$ during DNF is enhanced under oxidizing conditions.

Solute transport processes together with the POM rain rate and the composition of the overlying water control the redox conditions in sediments. Bioirrigation can enhance mineralization (Aller and Aller, 1998; Kristensen, 2001), which promotes reducing conditions, but this effect is opposed by the injection of oxic water, which leads to more oxidizing conditions. The benthic $\mathrm{N}$ isotope effect is largest under either strongly 
reducing or strongly oxidizing conditions, which correspond to combinations of low bioirrigation intensities and high mineralization rates and vice versa, or when shallow pumping leads to substantial recirculation of injected dissolved N. However, under conditions most commonly encountered in bioirrigated sediments, the benthic $\mathrm{N}$ isotope effect is estimated to be close to $-3 \%$, which is similar to previous estimates of the global N isotope effect (Lehmann et al., 2007; Somes et al., 2013). Such fractionation in sediments leads to substantially heavier $\mathrm{NO}_{\mathrm{x}}$ in the ocean, tilting the balance towards benthic $\mathrm{N}_{2}$ production, compared to estimates that ignore fractionation in marine sediments.

Acknowledgements: We would like to thank A. W. Dale and two anonymous reviewers for their constructive criticism and insightful comments, and T. Dornhoffer for his contributions to the bioirrigation model. The early development of the model was supported by the U.S. National Science Foundation (OCE 0751882 to CM) and JR was supported through Gulf of Mexico Research Initiative Ecological Impacts of Oil and Gas Inputs to the Gulf (ECOGIG-II to CM). This is ECOGIG contribution no. 364. 


\section{References}

Alkhatib M., Lehmann M. F. and Del Giorgio P. A. (2012) The nitrogen isotope effect of benthic remineralization-nitrification-denitrification coupling in an estuarine environment. Biogeosciences 9, 1633-1646.

Aller R. C. and Aller J. Y. (1998) The effect of biogenic irrigation intensity and solute exchange on diagenetic reaction rates in marine sediments. J. Mar. Res. 56, 905936.

Altabet M. A., Murray D. W. and Prell W. L. (1999) Climatically linked oscillations in Arabian Sea denitrification over the past 1 m.y.: Implications for the marine $\mathrm{N}$ cycle. Paleoceanography 14, 732-743.

Archer D. and Devol A. H. (1992) Benthic oxygen fluxes on the Washington shelf and slope: A comparison of in situ microelectrode and chamber flux measurements. Limnol. Oceanogr. 37, 614-629.

Baumann M. S., Moran S. B., Kelly R. P., Lomas M. W. and Shull D. H. (2013) ${ }^{234}$ Th balance and implications for seasonal particle retention in the eastern Bering Sea. Deep-Sea Res. 2 94, 7-21.

Bender M. L. (1990) The $\delta^{18} \mathrm{O}$ of dissolved $\mathrm{O}_{2}$ in seawater: a unique tracer of circulation and respiration in the deep sea. J. Geophys. Res. 95, 22243-22252.

Bianchi D., Dunne J. P., Sarmiento J. L. and Galbraith D. (2012) Data-based estimates of suboxia, denitrification, and $\mathrm{N}_{2} \mathrm{O}$ production in the ocean and their sensitivities to dissolved $\mathrm{O}_{2}$. Global Biogeochem. Cycles 26, GB2009.

Bohlen L., Dale A. W. and Wallman K. (2012) Simple transfer functions for calculating benthic fixed nitrogen losses and $\mathrm{C}: \mathrm{N}: \mathrm{P}$ regeneration ratios in global biogeochemical models. Global Biogeochem. Cycles, 26, GB3029.

Boudreau B. P. (1997) Diagenetic models and their implementation, $1^{\text {st }}$ ed., Springer, Berlin.

Boudreau B. P. (1996) The diffusive tortuosity of fine-grained unlithified sediments. Geochim. Cosmochim. Acta 60, 3139-3142.

Boudreau, B. P. (2001a) Solute transport above the sediment-water interface. In: Boudreau B. P. and Jørgensen B. B. (eds), The Benthic Boundary Layer, Oxford University Press, New York, pp. 104-126. 
Boudreau B. P., Huettel M., Forster S., Jahnke R. A., McLaghlan A., Middelburg J. J., Nielsen P., Sansone F., Taghon G., Van Raaphorst W., Webster I., Weslawski J. M., Wiberg P. and Sundby B. (2001b) Permeable Marine Sediments: Overturning and Old Paradigm. EOS 82, 133-136.

Brandes J. A., Devol A. H., Yoshinari T., Jayakumar D. A. and Naqvi S. W. A. (1998) Isotopic composition of nitrate in the central Arabian Sea and eastern tropical North Pacific: A tracer for mixing and nitrogen cycles. Limnol. Oceanogr. 43, 1680-1689.

Brandes J. A. and Devol A. H. (1997) Isotopic fractionation of oxygen and nitrogen in coastal marine sediments. Geochim. Cosmochim. Acta 61, 1793-1801.

Brandes J. A. and Devol A. H. (2002) A global marine-fixed nitrogen isotopic budget: Implications for Holocene nitrogen cycling. Global Biochem. Cycles 16, 1120.

Brandes J. A. and Devol A. H. (1995) Simultaneous nitrate and oxygen respiration in coastal sediments: Evidence for discrete diagenesis. J. Mar. Res. 53, 771-797.

Brunner B., Contreras S., Lehmann M. F., Matantseva O., Rollog M., Kalvelage T., Klockgether G., Lavik G., Jetten M. S. M., Kartal B. and Kuypers M. M. M. (2013) Nitrogen isotope effects induced by anammox bacteria. PNAS. http://dx.doi.org/ 10/1073/pnas.1310488110.

Carpenter E., Harvey H., Fry B. and Capone D. (1997): Biogeochemical tracers of the marine cyanobacterium Trichodesmium. Deep-Sea Res. 144, 27-38.

Casciotti K. L. (2009) Inverse kinetic isotope fractionation during bacterial nitrite oxidation. Geochim. Cosmochim. Acta 73, 2061-2076.

Dähnke K. and Thamdrup B. (2013) Nitrogen isotope dynamics and fractionation during sedimentary denitrification in Boknis Eck, Baltic Sea. Biogeosciences 10, 30793088.

Dale A. W., Sommer S., Ryabenko A., Noffke A., Bohlen L., Wallmann K., Stolpovsky K., Greinert J. and Pfannkuche O. (2014) Benthic nitrogen fluxes and fractionation of nitrate in the Mauritanian oxygen minimum zone (Eastern Tropical North Atlantic). Geochim. Cosmochim. Acta 134, 234-256.

D'Andrea A. F. and DeWitt T. H. (2009) Geochemical ecosystem engineering by the mud shrimp Upogebia pugettensis (Crustacea: Thalassinidae) in Yaquina Bay, 
Oregon: Density-dependent effects on organic matter remineralization and nutrient cycling. Limnol. Oceanogr. 54, 1911-1932.

Davenport E. S., Shull D. H. and Devol A. H. (2012) Roles of sorption and tube-dwelling benthos in the cycling of phosphorus in Bering Sea sediments. Deep-Sea Res. 2 65, 163-172.

Deutsch C., Sigman D. M., Thunell R. C., Meckler A. N. and Haug G. H. (2004) Isotopic constraints on glacial/interglacial changes in the oceanic nitrogen budget. Global Biogeochem. Cycles 18, GB4012.

Dornhoffer T. M., Waldblusser G. G. and Meile C. (2015) A modeling study of lugworm irrigation behavior effects on sediment nitrogen cycling. Mar. Ecol. Prog. Ser. 534, 121-134.

Emery K. O. (1968) Relict sediments on continental shelves of the world. Am. Assoc. Pet. Geol. Bull. 52, 445-464.

Fennel K., Brady D., DiToro D., Fulweiler R. W., Gardner W. S., Giblin A., McCarthy M. J., Rao A., Seitzinger S., Thouvenot-Korppoo M. and Tobias C. (2009) Modeling denitrification in aquatic sediments. Biogeochemistry 93, 159-178.

Granger J., Sigman D. M., Lehmann M. F. and Tortell P. D. (2008) Nitrogen and oxygen isotope fractionation during dissimilatory nitrate reduction by denitrifying bacteria. Limnol. Oceanogr. 53, 2533-2545.

Granger J., Prokopenko M. G., Sigman D. M., Mordy C. W., Morse Z. M., Morales L. V., Sambrotto R. N. and Plessen B. (2011) Coupled nitrification-denitrification in sediment of the eastern Bering Sea shelf leads to ${ }^{15} \mathrm{~N}$ enrichment of fixed $\mathrm{N}$ in shelf waters. J. Geophys. Res. 116, C11006.

Grundmanis V. and Murray J. W. (1977) Nitrification and denitrification in marine sediments from Puget Sound. Limnol. Oceanogr. 22, 804-813.

Hamersley M. R. and Howes B. L. (2004) Evaluation of the $\mathrm{N}_{2}$ flux approach for measuring sediment denitrification. Estuar. Coast. Shelf Sci. 62, 711-723.

Hüttel M. (1990) Influence of the lugworm Arenicola Marina on porewater nutrient profiles of sand flat sediments. Mar. Ecol. Prog. Ser. 62, 241-248.

Hüttel M., Røy H., Precht E., and Ehrenhauss S. (2003) Hydrological impact on biogeochemical processes in aquatic sediments. Hydrobiologia 494, 231-236. 
Jones S. E. and Jago C. F. (1993) In situ assessment of modification of sediment properties by burrowing invertebrates. Mar. Biol. 115, 133-142.

Kessler A. J., Glud R. N., Cardenas B., Larsen M., Bourke M. F. and Cook P. L. M. (2012) Quantifying denitrification in rippled permeable sands through combined flume experiments and modeling. Limnol. Oceanogr. 57, 1217-1232.

Kessler A. J., Bristow L. A., Cardenas M. B., Glud R. N., Thamdrup B. and Cook P. L. M. (2014) The isotope effect of denitrification in permeable sediments. Geochim. Cosmochim. Acta 133, 156-167.

Kristensen E. (2001) Impact of polychaetes (Nereis spp. and Arenicola marina) on carbon biogeochemistry in coastal marine sediments. Geochem. Trans. 2, 92-103.

Kritee K., Sigman D. M., Granger J., Ward B. B., Jayakumar A. and Deutsch C. (2012) Reduced isotope fractionation by denitrification under conditions relevant to the ocean. Geochim. Cosmochim. Acta 92, 243-259.

Künitzer A., Basford D., Craeymeersch J. A., Dewarumez J. M., Dörjes J., Duineveld G. C. A., Eleftheriou A., Heip C., Herman P., Kingston P., Niermann U., Rachor E., Rumohr H. and de Wilde P. A. J. (1992) The benthic infauna of the North Sea: species distribution and assemblages. ICES J. Mar. Sci. 49, 127-143.

Le Bars M. and Worster G. (2006) Interfacial conditions between a pure fluid and a porous medium: implications for binary alloy solidification. J. Fluid Mech. 550, 149-173.

Lehmann M. F., Sigman D. M. and Berelson W. M. (2004) Coupling the ${ }^{15} \mathrm{~N} /{ }^{14} \mathrm{~N}$ of nitrate as a constraint on benthic nitrogen cycling. Mar. Chem. 88, 1-20.

Lehmann M. F., Sigman D. M., McCorkle D. C., Granger J., Hoffmann S., Cane G. and Brunelle B. G. (2007) The distribution of nitrate ${ }^{15} \mathrm{~N} /{ }^{14} \mathrm{~N}$ in marine sediments and the impact of benthic nitrogen loss on the isotopic composition of oceanic nitrate. Geochim. Cosmochim. Acta 71, 5384-5404.

Lie U. (1968) A quantitative study of the benthic infauna in Puget Sound, Washington, USA in 1963-64. FiskDir. Skr. Ser. HavUnders 14, 229-556.

Lønborg C. and Søndergaard M. (2009) Microbial availability and degradation of dissolved organic carbon and nitrogen in two coastal areas. Estuar. Coast. Shelf Sci. 81, 513-520. 
Mariotti A., Germon J. C., Hubert P., Kaiser P., Letolle R., Tardieux R. and Tardieux P. (1981) Experimental determination of nitrogen kinetic isotope fractionation: some principles; illustration for the denitrification and nitrification processes. Plant Soil 62, 413-430.

Meile C. and Van Cappellen P. (2003) Global estimates of enhanced solute transport in marine sediments. Limnol. Oceanogr. 48, 777-786.

Meysman F. J. R., Middelburg J. J. and Heip C. H. R. (2006a) Bioturbation: a fresh look at Darwin's last idea. Trends Ecol. Evol. 21, 688-695.

Meysman F. J. R., Galaktionov O. S., Gribsholt B. and Middelburg J.J. (2006b) Bioirrigation in permeable sediments: Advective pore-water transport induced by burrow ventilation. Limnol. Oceanogr. 51, 142-156.

Middelburg J. J., Soetaert K. and Herman P. M. J. (1997) Empirical relationships for use in global diagenetic models. Deep-Sea Res. I 44, 327-344.

Minagawa M. and Wada E. (1986) Nitrogen isotope ratios of red tide organisms in the East-China-Sea - a characterization of biological nitrogen-fixation. Mar. Chem. 19, 245-259.

Montoya J. P. (2008) Chapter 29: Nitrogen Stable Isotopes in Marine Environments. In: Capone D., Carpenter E., Mullholland M., and Bronk D. (eds), Nitrogen in the marine environment. Elsevier, Amsterdam, pp. 1277-1302.

Na T., Gribsholt B., Galaktionov O. S., Lee T. and Meysman F. J. R. (2008) Influence of advective bio-irrigation on carbon and nitrogen cycling in sandy sediments. $J$. Mar. Res. 66, 691-722.

Nichols F. H. (2003) Interdecadal change in the deep Puget Sound benthos. Hydrobiologia 493, 95-114.

Pallud C. and Van Cappellen P. (2006) Kinetics of microbial sulfate reduction in estuarine sediments. Geochim. Cosmochim. Acta 70, 1148-1162.

Reitze M. and Schöttler U. (1989) The time dependence of adaption to reduced salinity in the lugworm Arenicola marina L. (Annelida: Polychaeta). Comp. Biochem. Physiol. 93, 549-559.

Riisgård H. U. and Banta G. T. (1998) Irrigation and deposit feeding by the lugworm Arenicola marina, characteristics and secondary effects on the environment. A 
review of current knowledge. Vie Milieu 48, 243-257.

Sarmiento J. L. and Gruber N. (2006) Ocean Biogeochemical Dynamics. Princeton University Press, Princeton.

Shearer G., Schneider J. D. and Kohl D. H. (1991) Separating the efflux and influx components of net nitrate uptake by Synechococcus-R2 under steady-state conditions. J. Gen. Microbiol. 137, 1179-1184.

Sigman D. M., Robinson R., Knapp A. N., van Geen A., McCorkle D. C., Brandes J. A., and Thunell R. C. (2003) Distinguishing between water column and sedimentary denitrification in the Santa Barbara Basin using the stable isotopes of nitrate. Geochem. Geophys. Geosyst. 4, 1040.

Somes C. J., Oschlies A. and Schmittner A. (2013) Isotopic constraints on the preindustrial oceanic nitrogen budget. Biogeosciences 10, 5889-5910.

Stief P. (2013) Stimulation of microbial nitrogen cycling in aquatic ecosystems by benthic macrofauna: mechanisms and environmental implications. Biogeosciences 10, 7829-7846.

Van Cappellen P. and Wang Y. F. (1995) Metal cycling in surface sediments: Modeling the interplay of transport and reaction. In: Allen H. E. (ed), Metal Speciation and Contamination of Aquatic Sediments. Ann Arbor Press, Chelsea, Michigan, pp. 21-64.

Volkenborn N., Hedtkamp S. I. C., Van Beusekom J. E. E. and Reise K. (2007) Effects of bioturbation and bioirrigation by lugworms (Arenicola Marina) on physical and chemical sediment properties and implications for intertidal habitat succession. Estuar. Coast. Shelf Sci. 74, 331-343.

Volkenborn N., Polerecky L., Wethey D. S. and Woodin S. A. (2010) Oscillatory porewater bioadvection in marine sediments induced by hydraulic activities of Arenicola marina. Limnol. Oceanogr. 55, 1231-1247.

Wang Y. F. and Van Cappellen P. (1996) A multicomponent reactive transport model of early diagenesis: application to redox cycling in coastal marine sediment. Geochim. Cosmochim. Acta 60, 2993-3014.

Wellman R. P., Cook F. D. and Krouse H. R. (1968) Nitrogen-15: Microbiological alteration of abundance. Science 161, 269-270. 


\section{Tables and Figures}

Table 1. Reactions and rate laws

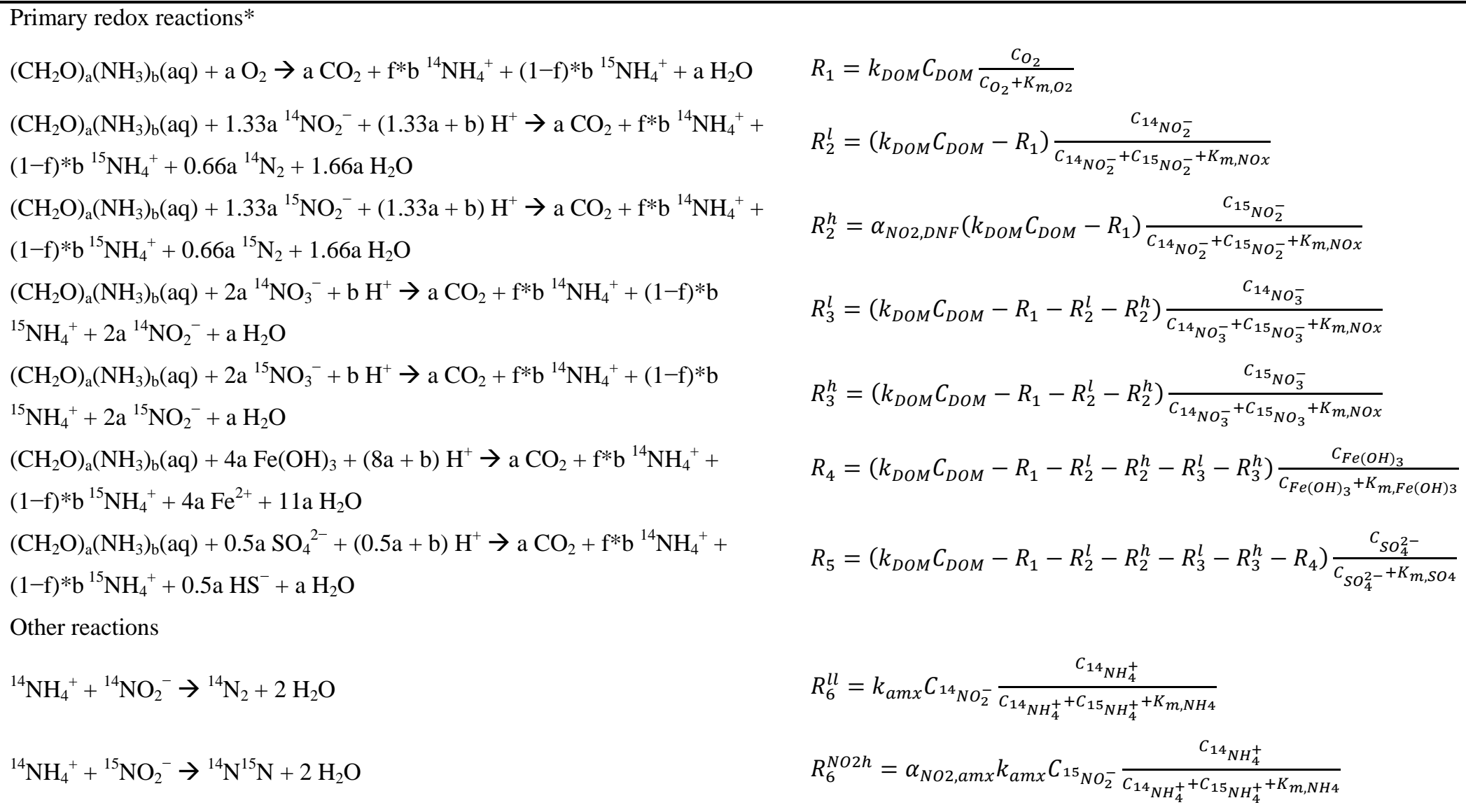

$R_{2}^{l}=\left(k_{D O M} C_{D O M}-R_{1}\right) \frac{C_{14} \mathrm{NO}_{2}^{-}}{C_{14} \mathrm{NO}_{2}^{-}}+C_{1 \mathrm{~N}_{\mathrm{NO}}^{-}}^{+K_{m, N O x}}$

$R_{2}^{h}=\alpha_{N O 2, D N F}\left(k_{D O M} C_{D O M}-R_{1}\right) \frac{C_{15_{N O}^{-}}}{C_{14 \mathrm{NO}_{2}^{-}}+C_{1 \mathrm{NO}_{2}^{-}}+K_{m, N O X}}$

$R_{3}^{l}=\left(k_{D O M} C_{D O M}-R_{1}-R_{2}^{l}-R_{2}^{h}\right) \frac{C_{14} \mathrm{NO}_{3}^{-}}{C_{14 \mathrm{NO}_{3}^{-}}+C_{1 \mathrm{NO}_{3}^{-}}+K_{m, \mathrm{NOX}}}$

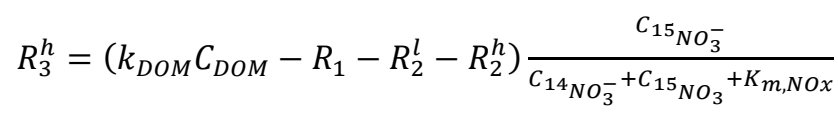

$R_{4}=\left(k_{D O M} C_{D O M}-R_{1}-R_{2}^{l}-R_{2}^{h}-R_{3}^{l}-R_{3}^{h}\right) \frac{C_{F e(O H)_{3}}}{C_{F e(O H)_{3}}+K_{m, F e(O H) 3}}$

$R_{5}=\left(k_{D O M} C_{D O M}-R_{1}-R_{2}^{l}-R_{2}^{h}-R_{3}^{l}-R_{3}^{h}-R_{4}\right) \frac{C_{S O_{4}^{2-}}}{C_{S O_{4}^{2-}}+K_{m, S O 4}}$

$R_{6}^{l l}=k_{a m x} C_{14} \mathrm{NO}_{2}^{-} \frac{\mathrm{C}_{14} \mathrm{NH}_{4}^{+}}{C_{14} \mathrm{NH}_{4}^{++C_{15} \mathrm{NH}_{4}^{+}}+K_{m, \mathrm{NH} 4}}$

$R_{6}^{N O 2 h}=\alpha_{N O 2, a m x} k_{a m x} C_{15} \mathrm{NO}_{2}^{-} \frac{C_{14} \mathrm{NH}_{4}^{+}}{C_{14} \mathrm{NH}_{4}^{+}{ }^{+C_{15} \mathrm{NH}_{4}^{+}}+K_{m, N H 4}}$ 


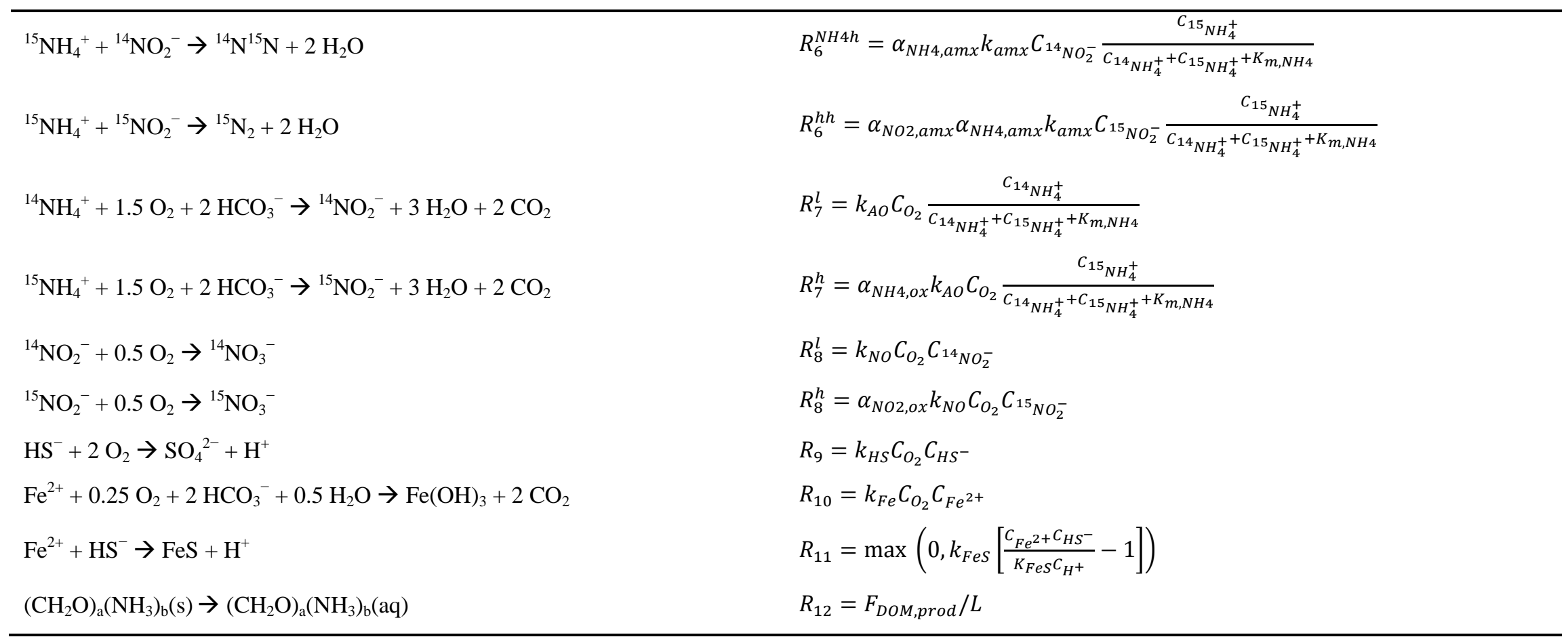

$*\left(\mathrm{CH}_{2} \mathrm{O}\right)_{\mathrm{a}}\left(\mathrm{NH}_{3}\right)_{\mathrm{b}}(\mathrm{aq})$ and $\left(\mathrm{CH}_{2} \mathrm{O}\right)_{\mathrm{a}}\left(\mathrm{NH}_{3}\right)_{\mathrm{b}}(\mathrm{s})$ refer to dissolved and particulate organic matter, respectively. ' $\mathrm{a}$ ' and ' $\mathrm{b}$ ' subscripts refer to the $\mathrm{C}: \mathrm{N}$ ratio in organic matter, which was set to 106:16. ' $\mathrm{f}$ ' denotes the fraction of ${ }^{14} \mathrm{~N}$ in organic matter $\left(\mathrm{f}={ }^{14} \mathrm{~N}:\left[{ }^{15} \mathrm{~N}+{ }^{14} \mathrm{~N}\right]\right) . L$ refers to the length of the modeled sediment domain, which is $20 \mathrm{~cm}$. 
Table 2. Parameters used in reaction-transport model (baseline)

\begin{tabular}{|c|c|c|c|}
\hline Description & Symbol & $\begin{array}{c}\text { Value or } \\
\text { Expression }\end{array}$ & Source \\
\hline \multicolumn{4}{|l|}{ Environmental parameters } \\
\hline Bottom water $\mathrm{O}_{2}$ concentration & $\mathrm{O}_{2, \mathrm{bw}}$ & $150 \mu \mathrm{M}$ & $\mathrm{a}$ \\
\hline Bottom water $\mathrm{NO}_{3}^{-}$concentration & $\mathrm{NO}_{3, \text { bw }}^{-}$ & $23 \mu \mathrm{M}$ & a \\
\hline Isotopic composition bottom water $\mathrm{NO}_{3}^{-}$ & $\delta^{15} \mathrm{~N}-\mathrm{NO}_{3, \mathrm{bw}}$ & $7.6 \%$ & a \\
\hline Isotopic composition organic $\mathrm{N}$ & Org. $\delta^{15} \mathrm{~N}$ & $7.0 \%$ & a \\
\hline Bottom water DOM concentration & $\mathrm{DOM}_{\mathrm{bw}}$ & $50 \mu \mathrm{M}$ & $\mathrm{b}$ \\
\hline Injected $\mathrm{O}_{2}$ concentration & $\mathrm{O}_{2, \text { inj }}$ & $0.4 * \mathrm{O}_{2, \mathrm{bw}}$ & $\mathrm{c}$ \\
\hline Injected $\mathrm{NH}_{4}{ }^{+}$concentration & $\mathrm{NH}_{4, \text { inj }}$ & $8 \mu \mathrm{M}$ & d \\
\hline Imposed $\mathrm{Fe}(\mathrm{OH})_{3}$ concentration & $\mathrm{Fe}(\mathrm{OH})_{3}$ & $5 \mathrm{mM}$ & \\
\hline $\mathrm{N}: \mathrm{C}$ of $\mathrm{POM}$ and $\mathrm{DOM}$ & $\mathrm{N}: \mathrm{C}$ & $16: 106$ & \\
\hline Porosity & $\Phi$ & 0.4 & \\
\hline Acidity & $\mathrm{pH}$ & 8.1 & \\
\hline In situ DOM production & $F_{\text {DOM,prod }}$ & $4 \mathrm{mmol} \mathrm{C} \mathrm{m}{ }^{-2} \mathrm{~d}^{-1}$ & $\mathrm{e}$ \\
\hline Pumping rate & Q & $0.62 \mathrm{~mL} \mathrm{~min}^{-1}$ & $\mathrm{e}$ \\
\hline \multicolumn{4}{|l|}{ Rate constants } \\
\hline DOM production & $\mathrm{k}_{\mathrm{DOM}}$ & $2 * 10^{-5} \mathrm{~s}^{-1}$ & $\mathrm{f}$ \\
\hline Anammox & $\mathrm{k}_{\mathrm{amx}}$ & $1.7 * 10^{-5} \mathrm{~s}^{-1}$ & $\mathrm{e}$ \\
\hline $\mathrm{NH}_{4}{ }^{+}$oxidation & $\mathrm{k}_{\mathrm{AO}}$ & $1.5 * 10^{-5} \mathrm{~s}^{-1}$ & $\mathrm{e}$ \\
\hline $\mathrm{NO}_{2}^{-}$oxidation & $\mathrm{k}_{\mathrm{NO}}$ & $6.3 * 10^{-7} \mu \mathrm{M}^{-1} \mathrm{~s}^{-1}$ & e \\
\hline $\mathrm{HS}^{-}$oxidation & $\mathrm{k}_{\mathrm{HS}}$ & $5.1 * 10^{-9} \mu \mathrm{M}^{-1} \mathrm{~s}^{-1}$ & $\mathrm{~g}$ \\
\hline $\mathrm{Fe}^{2+}$ oxidation & $\mathrm{k}_{\mathrm{Fe}}$ & $7.5 * 10^{-5} \mu \mathrm{M}^{-1} \mathrm{~s}^{-1}$ & $\mathrm{~h}$ \\
\hline FeS precipitation & $\mathrm{k}_{\mathrm{FeS}}$ & $1.9 * 10^{-12} \mu \mathrm{M}^{-1} \mathrm{~s}^{-1}$ & $\mathrm{~g}$ \\
\hline Half-sat. constant aerobic respiration & $\mathrm{K}_{\mathrm{m}, \mathrm{O} 2}$ & $8 \mu \mathrm{M}$ & $\mathrm{g}$ \\
\hline Half-sat. constant DNF & $\mathrm{K}_{\mathrm{m}, \mathrm{NOx}}$ & $12 \mu \mathrm{M}$ & $\mathrm{g}$ \\
\hline Half-sat. constant $\mathrm{Fe}(\mathrm{OH})_{3}$ reduction & $\mathrm{K}_{\mathrm{m}, \mathrm{Fe}(\mathrm{OH}) 3}$ & $50 * 10^{3} \mu \mathrm{M}$ & $\mathrm{h}$ \\
\hline Half-sat. constant $\mathrm{SO}_{4}{ }^{2-}$ reduction & $\mathrm{K}_{\mathrm{m}, \mathrm{SO} 4}$ & $850 \mu \mathrm{M}$ & $\mathrm{i}$ \\
\hline Half-sat. constant anammox and $\mathrm{NH}_{4}{ }^{+}$oxidation & $\mathrm{K}_{\mathrm{m}, \mathrm{NH} 4}$ & $10 \mu \mathrm{M}$ & $\mathrm{e}$ \\
\hline Dissociation constant FeS & $\mathrm{K}_{\mathrm{FeS}}$ & $1.12 \mathrm{mM}$ & $\mathrm{g}$ \\
\hline \multicolumn{4}{|l|}{ Fractionation factors: } \\
\hline Denitrification $\left(\mathrm{NO}_{2}^{-}\right)$ & $\alpha_{\mathrm{NO} 2, \mathrm{DNF}}$ & 0.985 & $\mathrm{j}$ \\
\hline Denitrification $\left(\mathrm{NO}_{3}^{-}\right)$ & $\alpha_{\mathrm{NO}, \mathrm{DNF}}$ & 0.979 & $\mathrm{j}$ \\
\hline Nitrification $\left(\mathrm{NH}_{4}^{+}\right)$ & $\alpha_{\mathrm{NH} 4, \mathrm{Ox}}$ & 0.984 & $\mathrm{e}$ \\
\hline
\end{tabular}




\begin{tabular}{llll}
\hline Nitrification $\left(\mathrm{NO}_{2}^{-}\right)$ & $\alpha_{\mathrm{NO} 2, \mathrm{ox}}$ & 1.013 & $\mathrm{j}$ \\
Anammox $\left(\mathrm{NO}_{2}{ }^{-}\right)$ & $\alpha_{\mathrm{NO} 2, \mathrm{amx}}$ & 0.982 & $\mathrm{k}$ \\
Anammox $\left(\mathrm{NH}_{4}{ }^{+}\right)$ & $\alpha_{\mathrm{NH} 4, \mathrm{amx}}$ & 0.984 & $\mathrm{e}$ \\
\hline
\end{tabular}

Sources: a) Brandes and Devol (1997), b) Lønborg and Søndergaard (2009), c) Volkenborn et al. (2010), d)

Reitze and Schöttler (1989), e) fitted to reproduce measurements of Brandes and Devol (1997), f)

Dornhoffer et al. (2015), g) Wang and Van Cappellen (1996), h) Van Cappellen and Wang (1995), i) Pallud and Van Cappellen (2005), j) from data compiled by Casciotti (2009), k) Brunner et al. (2013). 


\section{Figure captions}

Fig 1. Steady-state concentration fields and reaction rates from the baseline simulation. The contours in panel $b$ show the $\mathrm{NO}_{\mathrm{x}}$ concentrations of the simulation with a feeding pocket at $5 \mathrm{~cm}$ depth. The concentrations and rates in panels $\mathrm{c}$ and $\mathrm{f}$, respectively, are horizontally averaged over the domain.

Fig. 2. Nitrogen cycling in the baseline simulation, a) $\mathrm{N}$ fluxes and their isotopic composition: measurements of Brandes and Devol (1997) are underlined; 'resp. worm'

refers to $\mathrm{NH}_{4}{ }^{+}$produced during respiration by the worm, b) $\mathrm{NO}_{\mathrm{x}}$ concentration and associated isotope signature in a benthic chamber reflecting the conditions of Brandes and Devol (1997). Lines are calculated from fluxes of the baseline (solid) and sensitivity analysis of DOM reactivity (dashed), while filled circles represent the observations of Brandes and Devol (1997).

Fig. 3. Sensitivity of the $\mathrm{N}_{2}$ production rate $\left(\mathrm{mmol} \mathrm{m}^{-2} \mathrm{~d}^{-1}\right)$ and benthic $\mathrm{N}$ isotope effect towards a) the pumping rate, b) the domain radius with a burrow depth of $15 \mathrm{~cm}$ and 5 $\mathrm{cm}, \mathrm{c})$ the reactivity of dissolved organic matter, d) the bottom water $\mathrm{O}_{2}$ concentration, e) the bottom water $\mathrm{NO}_{3}{ }^{-}$concentration, and f) the in situ dissolved organic matter production rate. Stacked bars show the contribution of individual processes (see also Eq. 11). Asterisks indicate the values used in the baseline simulation.

Fig. 4. The combined effect of the mineralization rate and bioirrigation intensity on the benthic $\mathrm{N}$ isotope effect ( $\varepsilon_{\text {sed }}$, solid contour lines). The dashed line corresponds to Eq. 12. The dotted contour delineates the region in which the model computed $\mathrm{N}_{2}$ flux is within \pm $10 \%$ of Eq. 13. 


\section{Figureitaplor}

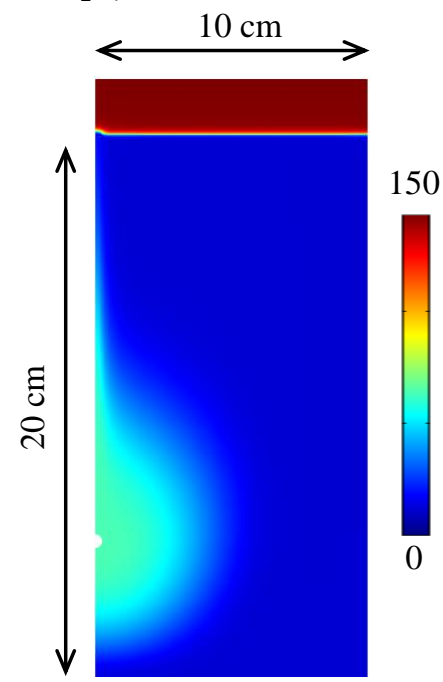

d) $\mathrm{NH}_{4}{ }^{+}$ox. $\left(\mu \mathrm{mol} \mathrm{N} \mathrm{cm}{ }^{-3} \mathrm{y}^{-1}\right)$

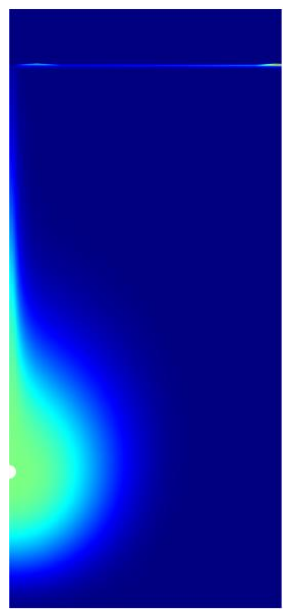

b) $\mathrm{NO}_{\mathrm{x}}(\mu \mathrm{M})$

c) Concentration profiles $(\mu \mathrm{M})$
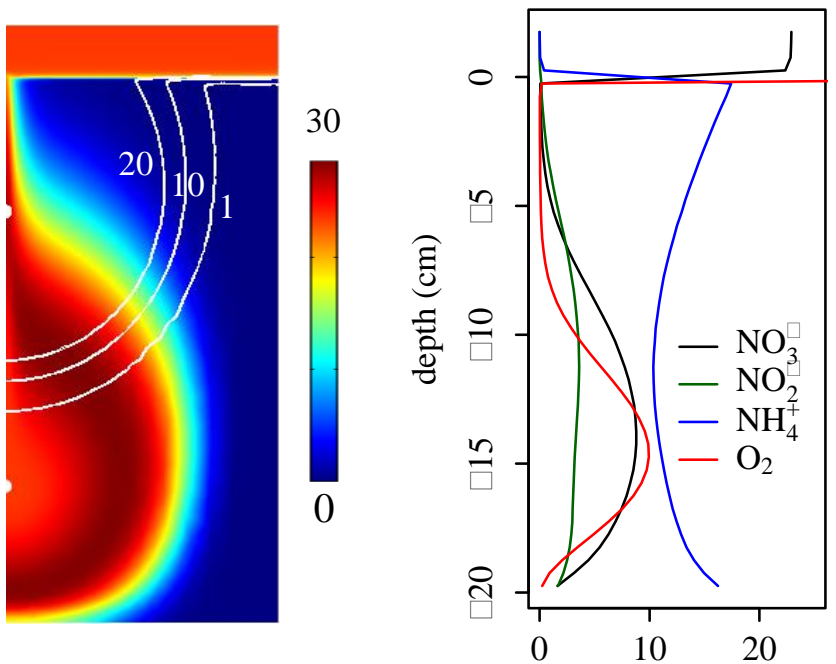

e) $\mathrm{N}_{2}$ prod. ( $\left.\mu \mathrm{mol} \mathrm{N} \mathrm{cm} \mathrm{y}^{-3} \mathrm{y}^{-1}\right)$ f) Rate profiles $\left(\mu \mathrm{mol} \mathrm{N} \mathrm{cm}{ }^{-3}\right.$

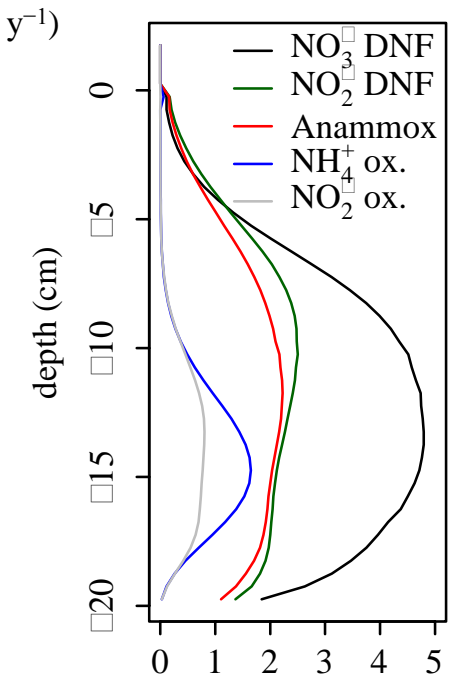


c) Concentration profiles $(\mu \mathrm{M})$
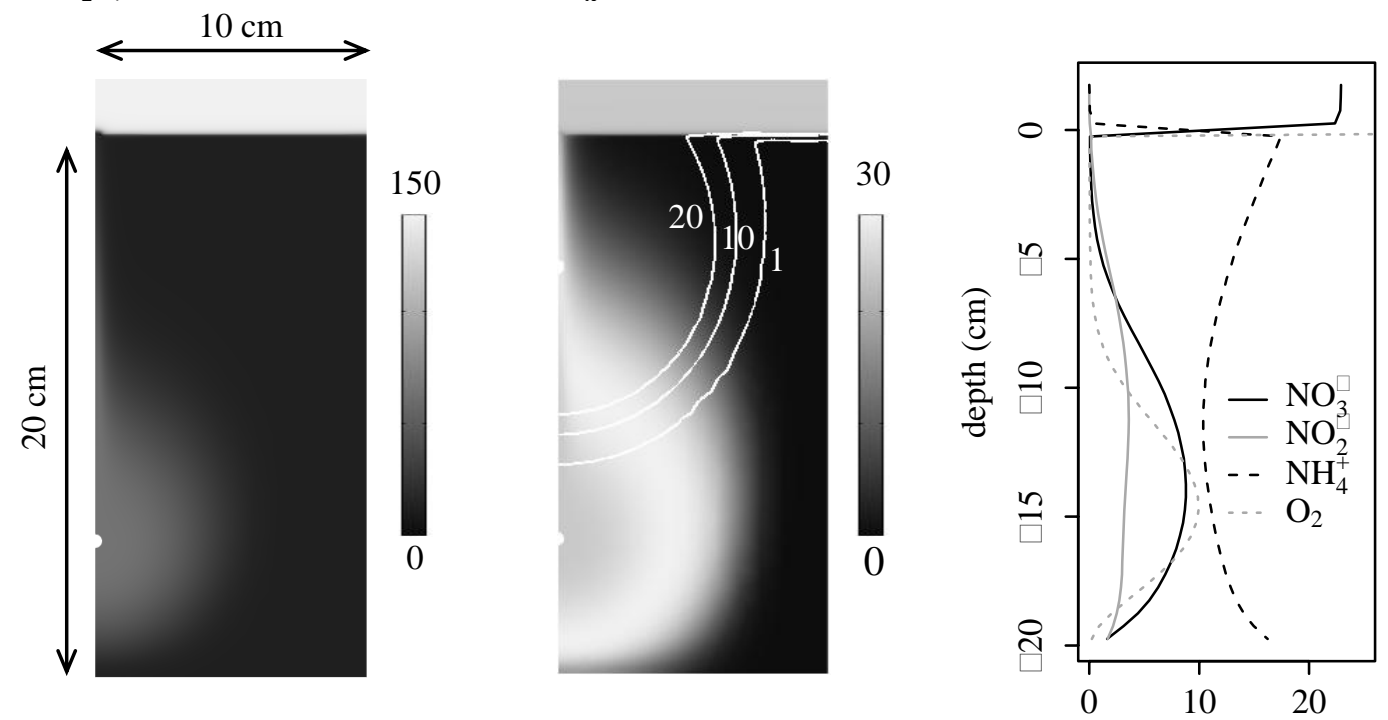

d) $\mathrm{NH}_{4}{ }^{+}$ox. $\left(\mu \mathrm{mol} \mathrm{N} \mathrm{cm}{ }^{-3} \mathrm{y}^{-1}\right)$
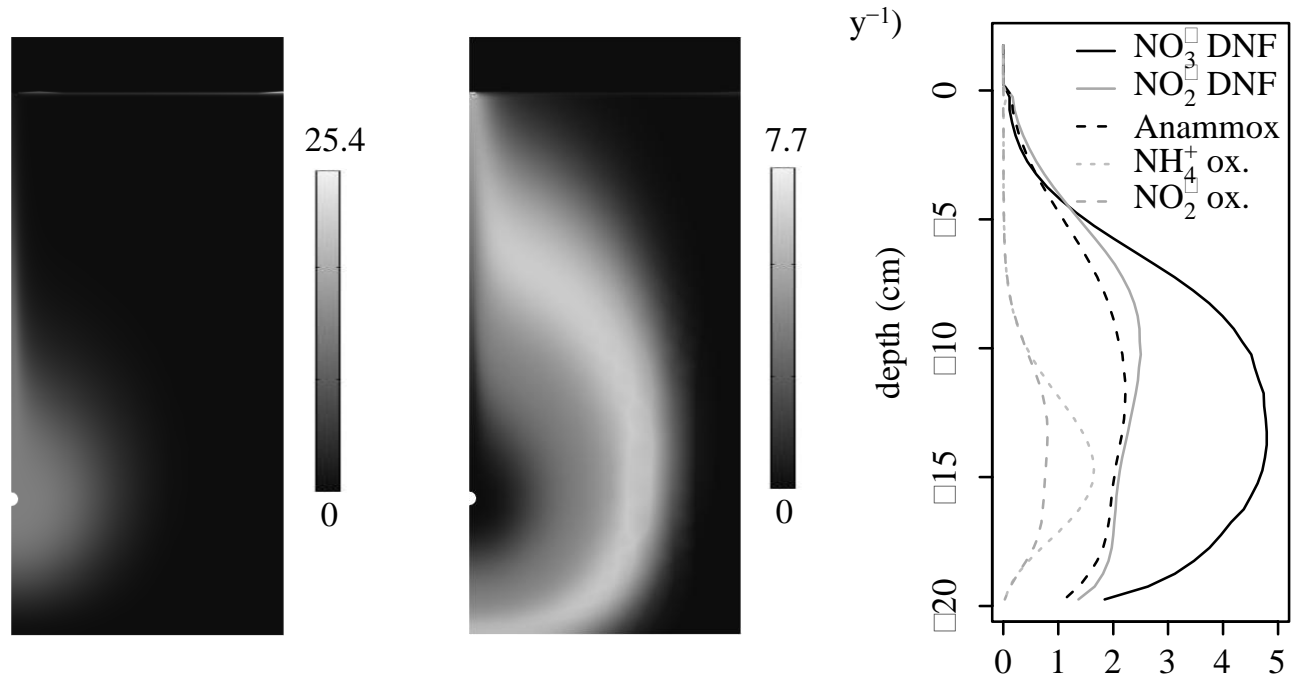
Figure2

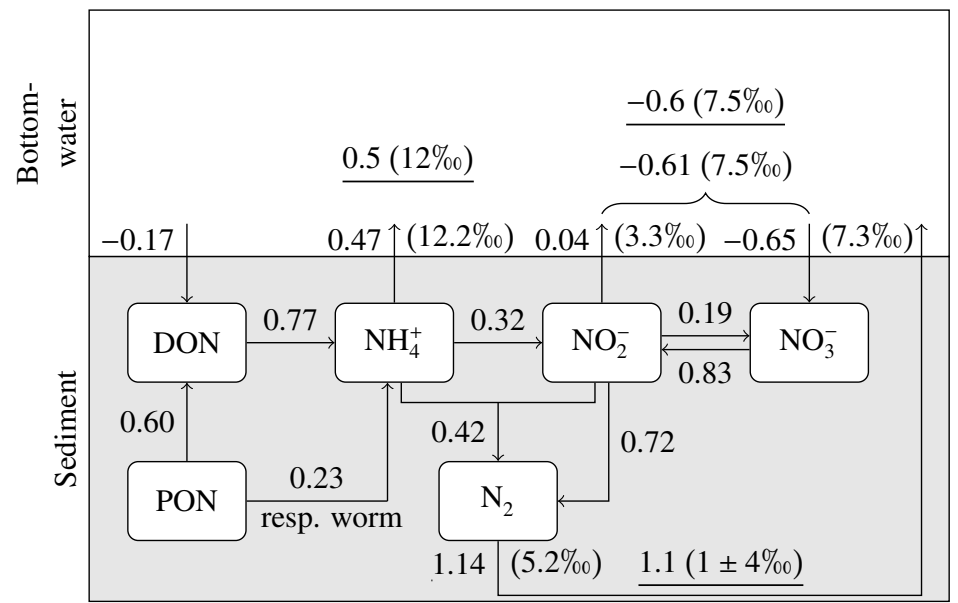

- - $2 \cdot 10^{-7} \cdots \cdots \cdot 2 \cdot 10^{-6}$

$-2 \cdot 10^{-5}-\cdot \cdot \cdot 2 \cdot 10^{-4}$
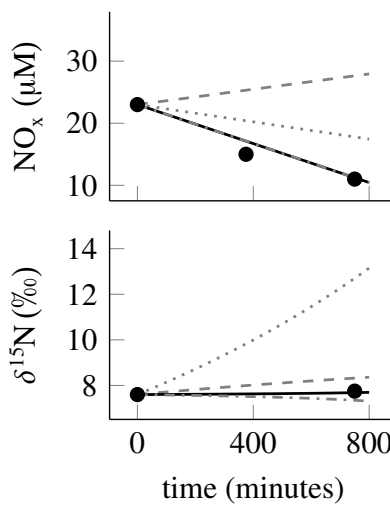


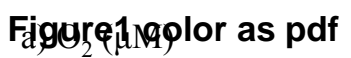

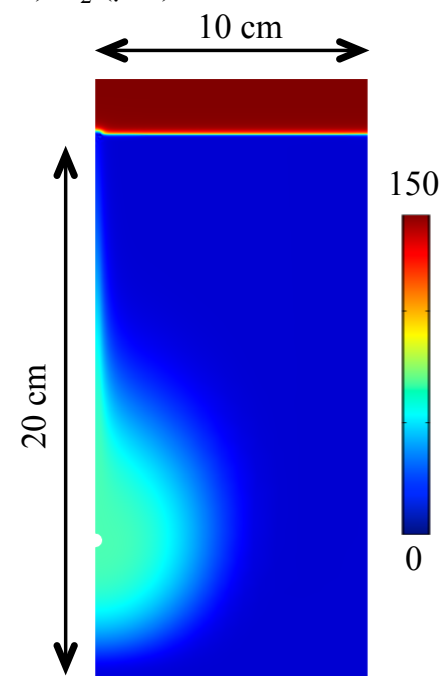

d) $\mathrm{NH}_{4}^{+}$ox. $\left(\mu \mathrm{mol} \mathrm{N} \mathrm{cm}{ }^{-3} \mathrm{y}^{-1}\right)$

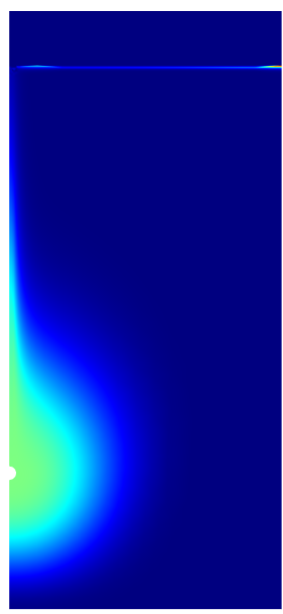

b) $\mathrm{NO}_{\mathrm{x}}(\mu \mathrm{M})$

c) Concentration profiles $(\mu \mathrm{M})$

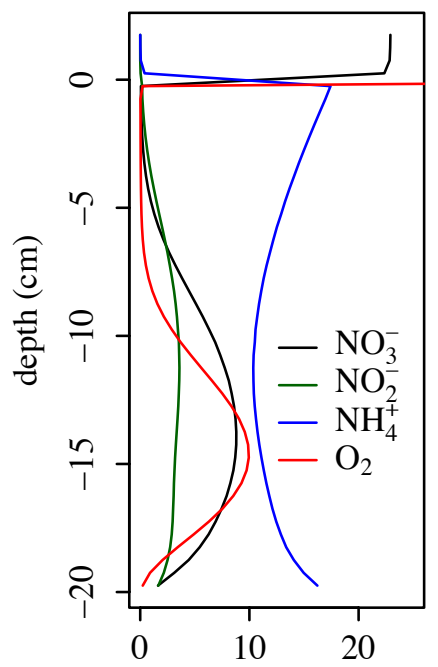

e) $\mathrm{N}_{2}$ prod. $\left(\mu \mathrm{mol} \mathrm{N} \mathrm{cm}{ }^{-3} \mathrm{y}^{-1}\right)$ f) Rate profiles $\left(\mu \mathrm{mol} \mathrm{N} \mathrm{cm}{ }^{-3} \mathrm{y}^{-1}\right)$

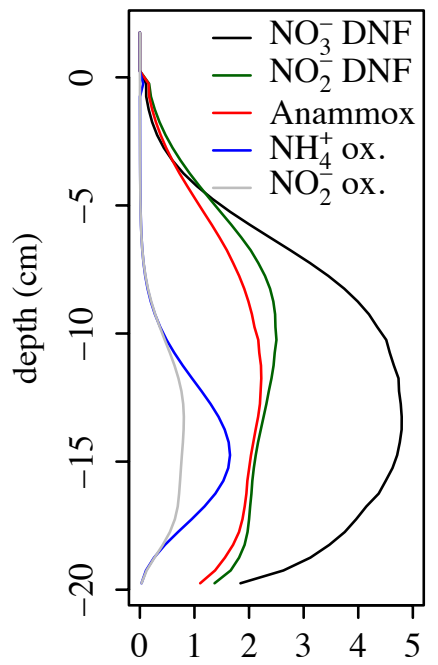


c) Concentration profiles $(\mu \mathrm{M})$
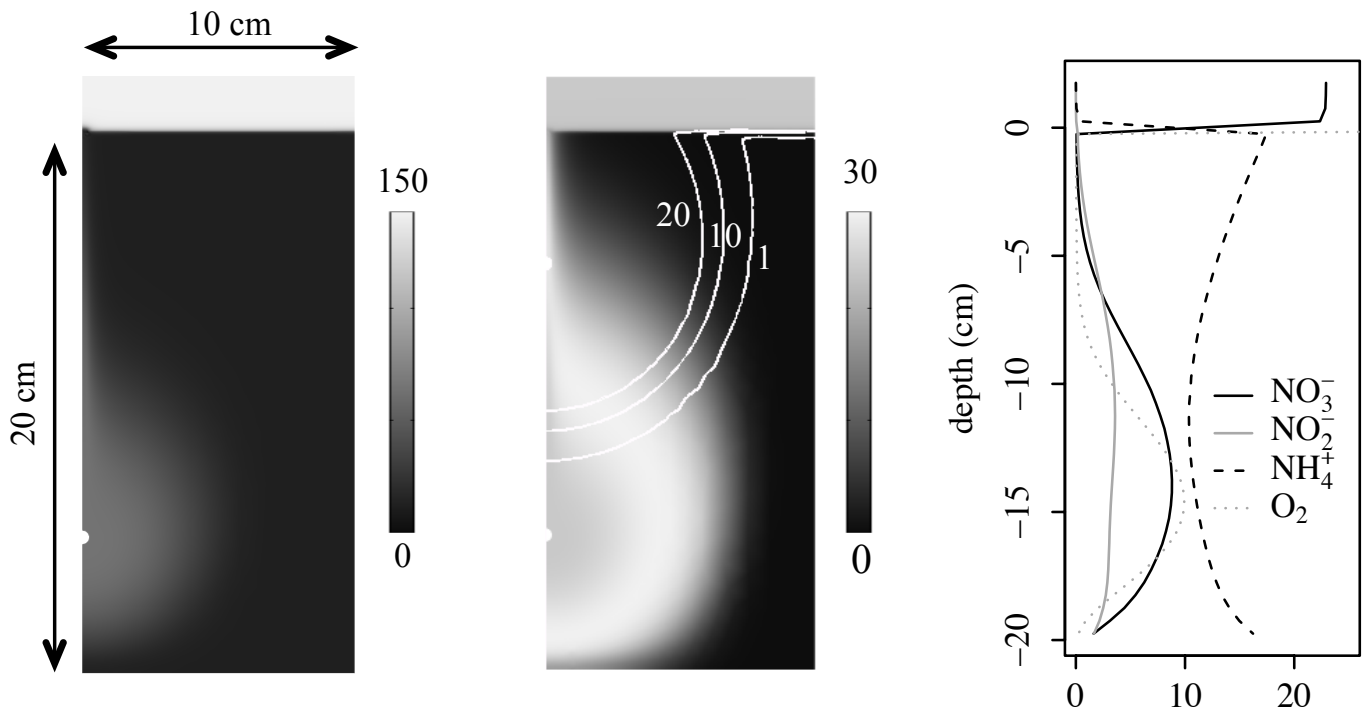

d) $\mathrm{NH}_{4}{ }^{+}$ox. $\left(\mu \mathrm{mol} \mathrm{N} \mathrm{cm}{ }^{-3} \mathrm{y}^{-1}\right)$

e) $\mathrm{N}_{2}$ prod. $\left(\mu \mathrm{mol} \mathrm{N} \mathrm{cm}{ }^{-3} \mathrm{y}^{-1}\right)$ f) Rate profiles $\left(\mu \mathrm{mol} \mathrm{N} \mathrm{cm}{ }^{-3} \mathrm{y}^{-1}\right)$
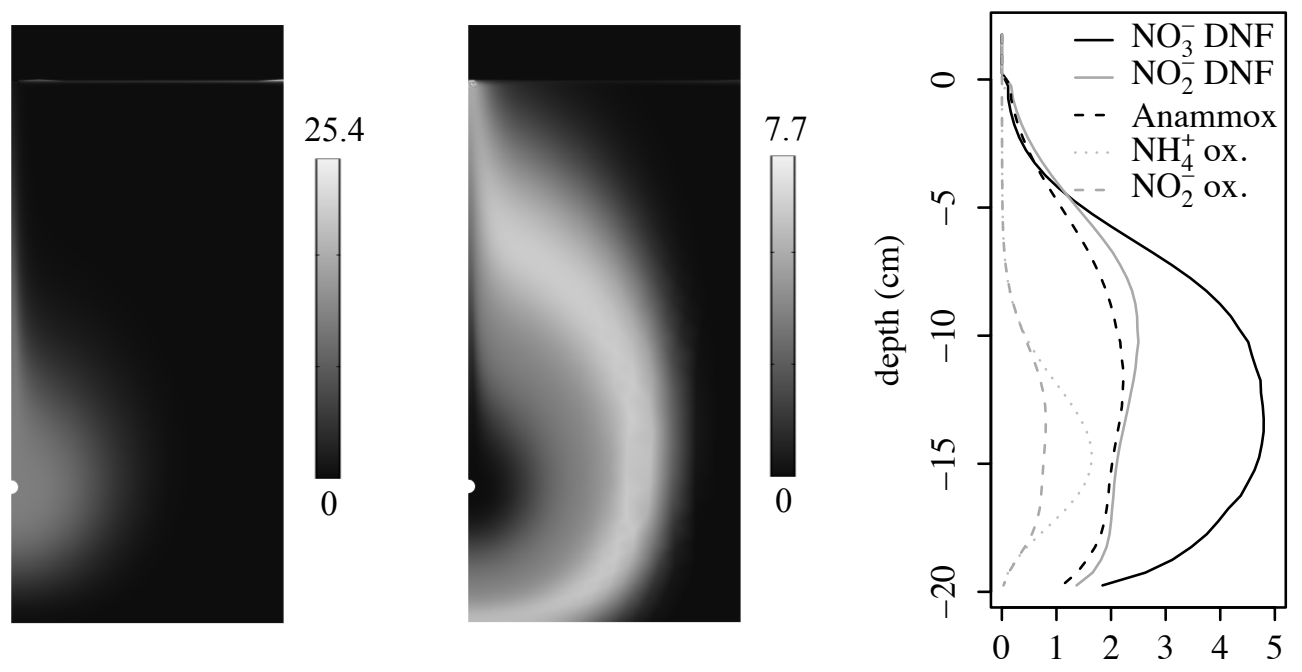